\title{
The Gondwana connections of northern Patagonia
}

\author{
R. J. PANKHURST ${ }^{1 *}$, C. W. RAPELA², M. G. LÓPEZ DE LUCHI ${ }^{3}$, A. E. RAPALINI ${ }^{4}$, C. M. \\ FANNING ${ }^{5} \&$ C. GALINDO 6 \\ ${ }^{1}$ British Geological Survey, Keyworth NG12 5GG, UK \\ ${ }^{2}$ Centro de Investigaciones Geológicas, Universidad Nacional de La Plata, 644 Calle No. 1, 1900 La Plata, \\ Argentina ${ }^{3}$ Instituto de Geocronología y Geología Isotópica (INGEIS), Universidad de Buenos Aires-CONICET, \\ Ciudad Universitaria, 1428 Buenos Aires, Argentina \\ ${ }^{4}$ Instituto de Geociencias Básicas, Aplicadas y Ambientales de Buenos Aires, Departamento de Ciéncias \\ Geológicas, Universidad de Buenos Aires-CONICET, Ciudad Universitaria, 1428 Buenos Aires, Argentina \\ ${ }^{5}$ Research School of Earth Sciences, The Australian National University, Canberra, ACT 201, Australia \\ ${ }^{6}$ Departamento de Petrología y Geoquímica, Universidad Complutense de Madrid-IGEO (UCM, CSIC), Madrid \\ 28040, Spain \\ *Corresponding author (e-mail: rjpankhurst@gmail.com)
}

\begin{abstract}
A multidisciplinary study ( $\mathrm{U}-\mathrm{Pb}$ sensitive high-resolution ion microprobe geochronology, $\mathrm{Hf}$ and $\mathrm{O}$ isotopes in zircon, $\mathrm{Sr}$ and $\mathrm{Nd}$ isotopes in whole-rocks, as well as major and trace element geochemistry) has been carried out on granitoid samples from the area west of Valcheta, North Patagonian Massif, Argen-tina. These confirm the Cambrian age of the Tardugno Granodiorite $(528 \pm 4 \mathrm{Ma})$ and the Late Permian age of granites in the central part of the Yaminué complex (250 Ma). Together with petrological and structural information for the area, we consider a previously suggested idea that the Cambrian and Ordovician granites of northeastern Patagonia represent continuation of the Pampean and Famatinian orogenic belts of the Sierras Pampeanas, respectively. Our interpretation does not support the hypothesis that Patagonia was accreted in Late Palaeozoic times as a far-travelled terrane, originating in the Central Transantarctic Mountains, and the arguments for and against this idea are reviewed. A parautochthonous origin is preferred with no major ocean closure between the North Patagonian Massif and the Sierra de la Ventana fold belt.
\end{abstract}

Supplementary material: U-Pb SHRIMP analytical data, geochemical analyses and sample global position-ing system locations are available at www.geolsoc.org.uk/SUP18722.

The hypothesis that Patagonia originated as a far-travelled terrane that became accreted to the rest of South America in Late Palaeo-zoic times (Ramos 1984) has proved remarkably resilient. It pro-poses collision of a Patagonian terrane with the rest of South America along a hypothetical suture now buried beneath the Río Colorado basin (Fig. 1), causing NE-vergent deformation in the Palaeozoic sedimentary succession of the Sierra de la Ventana (Sierras Australes) and SW-vergent thrusting in northern Patago-nia (von Gosen 2003, and references therein). Nevertheless, despite years of further investigation, relevant evidence is still scarce and sometimes inconclusive. Whereas some geophysical surveys have been claimed to show a major crustal discontinuity along the proposed suture zone (e.g. Chernicoff \& Zappettini 2004), others have emphasized the complexity of the underlying block structure and the importance of east-west displacements, but did not indicate an overall difference in gravimetric signature across the boundary (Kostadinoff et al. 2005; Gregori et al. 2008). Palaeomagnetic data permit, but do not require, a small separation of the landmasses on either side in Devonian times (Rapalini 2005). Other researchers have argued that Patagonia was an autochthonous part of South America (e.g. Varela et al. 1991; Dalla Salda et al. 1992). Rapela \& Pankhurst (2002) and Pankhurst et al. (2003) supported the idea that the Early Palaeozoic Pampean and Famatinian magmatic belts of the Sierras Pampeanas might be traced continuously into the basement of the Sierra de la Ventana and northeastern Patagonia, respectively. Pankhurst et al. (2006) emphasized the idea that the North Patagonian Massif at least was an autochthonous part of South America, with a Carboniferous collision zone farther to the SW. A compromise parautochthonous scenario was proposed by López de Luchi et al. (2010) and Rapa-lini et al. (2010), but the discovery of blocks of archaeocyathid-bearing limestone in the Early Palaeozoic sedimentary rocks of NE Patagonia has reinvigorated the case for a distant source, adja-cent to the central Transantarctic Mountains (González et al. 2011). This paper presents new geochronological and geochemical evidence from the granites of northernmost Patagonia that is con-sistent with the continuity of two separate Early Palaeozoic mag-matic belts across the Río Colorado, and confirms the absence of Late Palaeozoic pre-collisional subduction magmatism required by accretion through ocean closure.

\section{Magmatism, subduction and collision in northern Patagonia}

The Palaeozoic (Cambrian? to Permian) siliciclastic rocks of the Sierra de la Ventana (Harrington 1972) are generally correlated with those of the Cape Fold Belt of southern Africa, representing a predominantly passive margin sequence, so that the collision model of Ramos $(1984,2008)$ has always been based on ocean closure by SW-dipping subduction during Late Palaeozoic times, followed by Carboniferous or Permian collision. This implies subduction-related magmatism in northern Patagonia preceding collision, for 


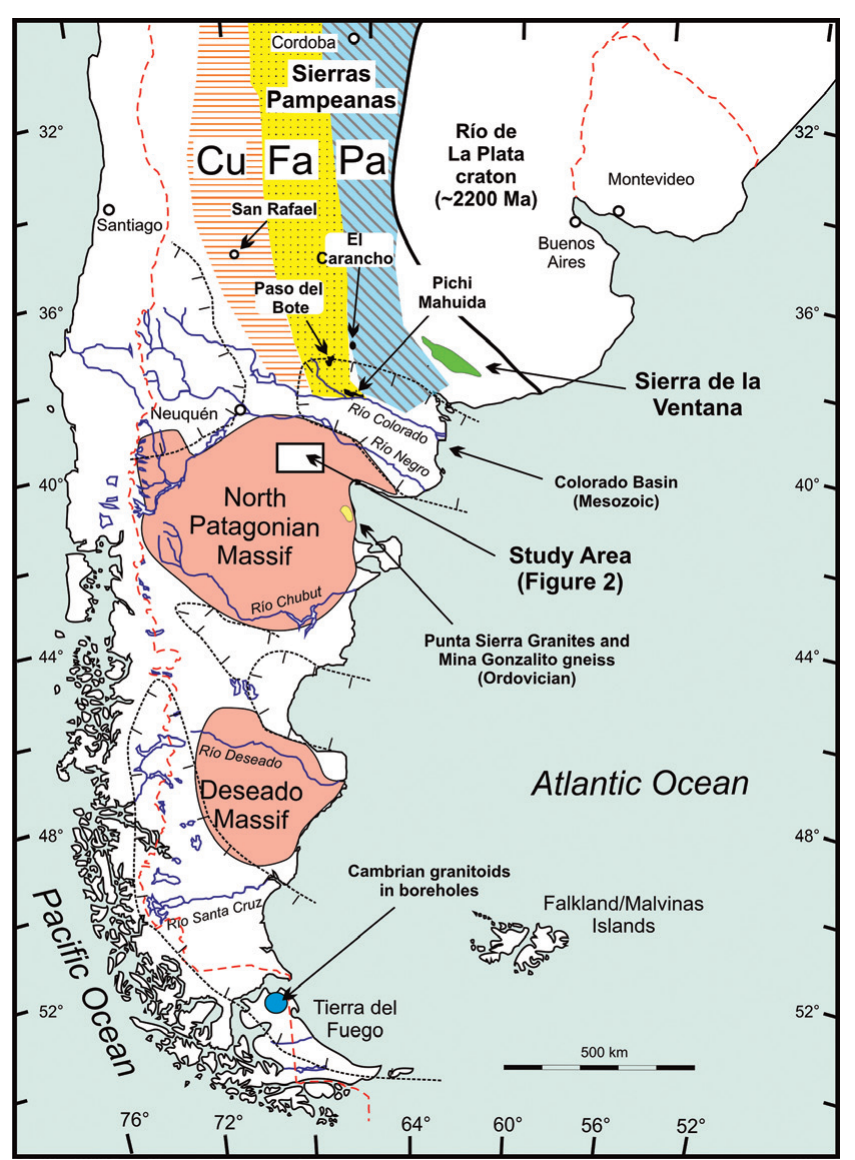

Fig. 1. Geological setting of Patagonia, Sierra de la Ventana and Sierras Pampeanas. Localities referred to in the text are indicated. $\mathrm{Cu}$, Cuyania (Precordillera terrane); Fa, Famatinian orogen; $\mathrm{Pa}$, Pampean orogen.

which an age span has been invoked as 310-285 Ma (Ramos 2008) or 395-300 Ma (Ramos \& Naipauer 2012). However, the Carboniferous attribution of widespread granites in the North Patagonian Massif underpinning the initial hypothesis was dis-pelled by the $\mathrm{Rb}-\mathrm{Sr}$ isochrons of Pankhurst et al. (1992), who showed that they are predominantly Permo-Triassic (subsequently confirmed by U-Pb zircon dating), partly sub-volcanic, and related to extensive felsic volcanism (Rapela \& Llambías 1985). The Permo-Triassic magmatism of northern Patagonia has been inter-preted as emplaced during an extensional phase, in keeping with the normal interpretation of the Choiyoi volcanism, a widespread event farther north in South America (e.g. Kay et al. 1989).

$\mathrm{U}-\mathrm{Pb}$ zircon dating (both conventional and sensitive highresolu-tion ion microprobe (SHRIMP)) has also established the presence of Ordovician granitoids in the extreme NE of the massif (Varela et al. 2005; Pankhurst et al. 2006; Rapalini et al. 2013), often referred to as the Punta Sierra suite (mostly 470-480 Ma). Pankhurst et al. (2006) presented firm evidence of Carboniferous magmatism, but on the western margin of the massif, where c. 330 Ma l-type grani-toids were followed by c. $325 \mathrm{Ma}$ anatectic granites, suggesting col-lision following NE-dipping subduction, but not along the Río Colorado; a scenario more consistent with the long-lived subduction of proto-Pacific crust beneath western Gondwana (Cawood 2005).

Ramos (2008) subsequently modified the allochthoneity hypoth-esis to include subduction zones on both NE and SW margins of the North Patagonian Massif, and two separate collisions, with Carboniferous accretion of a western terrane (the Antarctic
Peninsula?) preceding Early Permian collision of the amalgamated Patagonia terrane in the original sense. He reaffirmed the idea of a Carboniferous-Early Permian subduction-related magmatic arc along the northern part of the North Patagonian Massif, as noted above (see also Ramos \& Naipauer 2012). The principal evidence cited for the antiquity of this northern arc came from $\mathrm{U}-\mathrm{Pb}$ zircon ages obtained by Basei et al. (2002) of $305 \pm 31$ Ma for granitoids of the Yaminué complex and $300 \pm 6$ $\mathrm{Ma}$ for the Tardugno Granodiorite, both located west of Valcheta (Fig. 2), and both pre-viously thought to be Precambrian (Caminos et al. 1994; Chernicoff \& Caminos 1996). Unfortunately, these U-Pb data, obtained from multi-grain zircon samples, are scattered and not very convincing. The present study was initially undertaken to re-collect and date samples from the same critical localities. Meanwhile, the first U-Pb SHRIMP ages on zircon to be carried out in this area have been published: Chernicoff et al. (2013) obtained a new age of $261 \pm 3$ Ma for zircon from granite from the western part of the Yaminué complex, and Rapalini et al. (2013) have reported an Ordovician age of $467 \pm 7 \mathrm{Ma}$ for the southernmost sector of the complex and a Cambrian age of $529 \pm 4 \mathrm{Ma}$ for the Tardugno Granodiorite. These widely differing ages emphasize the need for more comprehensive study incorporating geochronology, geochemistry and isotope data to characterize the evolution and nature of Yaminué-Tardugno magmatism, which we have attempted to address here.

\section{The Yaminué complex}

The Yaminué complex (sensu López de Luchi et al. 2010, and ref-erences therein) occurs near the northern margin of the massif and largely consists of foliated granitoids and locally undeformed N-S- to NNW-SSE-trending leucogranitic dykes. The poorly exposed host rock is a biotite-muscovite schist or gneiss in the northern sector, whereas in the southern sector deformed granitoids are in assumed tectonic contact with marbles of unknown age. Chernicoff et al. (2013) described and dated as postMississippian the deposi-tional protolith of biotite schist from near Puesto Peynecura in the southern sector, which they considered to be synsedimentary with the marbles.

The igneous rocks of the complex are mostly shallowly NE-dipping sheet-like bodies of foliated porphyritic biotite grano-diorite-monzogranite (with scarce amphibole), and less common equigranular to porphyritic biotite tonalite. These are separated by sub-concordant sheets of mostly tonalitic biotite orthogneiss, a finegrained equigranular to porphyritic leucogranite and some pegmatite sills. In the central part of the complex, less-foliated amphibole-biotite tonalite and granodiorite with mafic microgran-ular enclaves occur. The porphyritic granitoids are megacrystic (plagioclase in the tonalite and K-feldspar in the granodiorite-mon-zogranite, both set in a coarse-grained quartz-feldspar matrix). Biotite is the main mafic mineral, with apatite, epidote and opaque minerals as accessories. Deformation, either synmagmatic or solid state while still at high temperature, developed a penetrative planar fabric and parallel high-strain zones, including metreto-decimetre sheets of mostly tonalitic orthogneiss.

\section{The Tardugno Granodiorite}

Chernicoff \& Caminos (1996) defined the Tardugno Granodiorite as a porphyritic granodiorite variably affected by heterogeneous foliation. The granodiorite is in contact with the Nahuel Niyeu Formation metasedimentary rocks along a steeply dipping NE-SW-trending mylonitic shear zone. Kinematic indicators demonstrate top-to-the-SW sense of shear of the hanging wall (von Gosen 2003). 


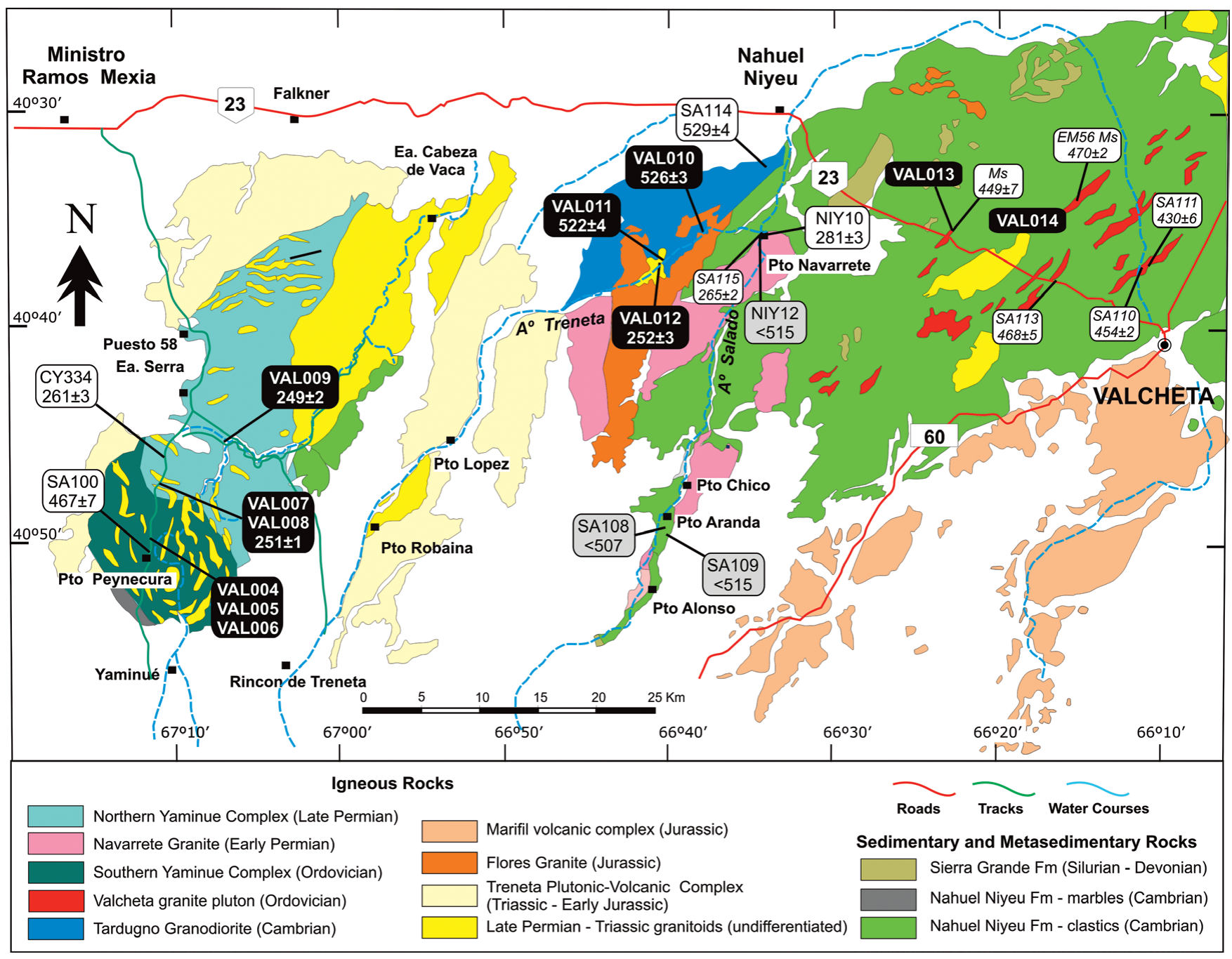

Fig. 2. Yaminué-Tardugno-Valcheta area with sample localities and geochronological results: values in normal type are U-Pb zircon SHRIMP ages; black boxes indicate results presented here; others are from Pankhurst et al. (2006), Chernicoff et al. (2013) and Rapalini et al. (2013). Ages in italics are $\mathrm{Ar}-\mathrm{Ar}$ or $\mathrm{K}-\mathrm{Ar}$ ages from Tohver et al. (2008), Gozalvez (2009) and Rapalini et al. (2013).

The main rock type is porphyritic biotite granodioritemonzo-granite orthogneiss with perthitic K-feldspar megacrysts, partially converted to microcline. The dominant fabric is of S-C type, defined by biotite (partly chloritized), chlorite and trails of dynam-ically recrystallized quartz; kinked and bent muscovite occurs locally. Kfeldspar porphyroclasts generally lack fracturing and micro-kink bands but locally show core-and-mantle structures cut by narrow shears with intense grain-size reduction zones. In more deformed areas, the porphyroclasts are polygonized with well-developed triple points between the crystals. At high strain a com-positional layering is produced with alternation of fine-grained mica-rich domains and fine-grained quartz-feldspar aggregates and polycrystalline quartz ribbons. There is evidence of both grain-boundary migration and sub-grain rotation recrystallization. The coexistence of recrystallized feldspar and quartz suggests peak metamorphic temperatures of $400-500{ }^{\circ} \mathrm{C}$ (Passchier \& Trouw 2005). Chlorite and epidote record retrogression of the original magmatic minerals during low-temperature deformation. Shear-sense indicators suggest dextral displacement in the mylonites. The Tardugno Granodiorite is intruded by mostly undeformed biotite tonalite-granodiorite, which exhibits a WNW-ESE magmatic fabric dipping $20^{\circ} \mathrm{NE}$ and a subhorizontal strike-parallel lineation (López de Luchi et al. 2010).
This rock is medium-grained, equig-ranular and hypidiomorphic, consisting of plagioclase $(50 \%)$, quartz (20\%), K-feldspar (15\%) and mafic minerals (15\%, dominantly bio-tite and less abundant magnetite). Accessory minerals include abun-dant apatite, titanite, zircon and scarce allanite. Variably developed parallel orientation of plagioclase laths and biotite flakes defines a magmatic flow foliation, as interstitial spaces as well as original crystalline shapes are preserved. The characteristic mineral assem-blage is subhedral zoned plagioclase (andesine to oligoclase), two generations of biotite and locally subhedral micro-perthitic K-feldspar. Quartz is mostly undeformed and interstitial. Biotite appears both as large flakes with inclusions and in aggregates of tiny flakes that could be pseudomorphs of amphibole. Accessory miner-als are apatite, titanite and scarce isolated crystals of allanite. Zircon is abundant and mostly euhedral, associated either with biotite (with pleochroic haloes) or with magnetite.

\section{The Valcheta pluton}

The Valcheta pluton is exposed as small, isolated outcrops intruded into the Nahuel Niyeu Formation for more than 40 $\mathrm{km}$ north and west of the town of Valcheta (Fig. 2). The magmatic association 
comprises muscovite granites with very fine-grained granite dykes; the former are grey or pinkish, equigranular and allotriomorphic leucogranites composed of quartz (48\%), orthoclase-microcline (30\%), weakly zoned oligoclase $(15 \%)$, muscovite $(5 \%)$, scarce variably chloritized biotite and zircon, apatite and opaque minerals. Minor amounts of garnet were described by Gozalvez (2009). As muscovite is a primary magmatic phase, pressure would have exceeded 3.5 kbar during emplacement. Although no penetrative planar fabric was observed.

$\mathrm{K}-\mathrm{Ar}$ and $\mathrm{Ar}-\mathrm{Ar}$ cooling ages for the Valcheta granites fall in the interval 470-430 Ma (López de Luchi et al. 2008; Tohver et al. 2008; Gozalvez 2009; Rapalini et al. 2013). The oldest ages corre-spond to the more central parts of the pluton whereas the youngest cooling age $(430 \pm 6 \mathrm{Ma})$ was obtained from a pink aplo-pegmatitic monzogranite dyke located close to the eastern contact (Rapalini et al. 2013). The Valcheta pluton may be assumed to be contempo-raneous with the Early Ordovician Punta Sierra granites to the SE, although because the only ages refer to cooling it could conceiva-bly be somewhat older.

\section{Samples}

Two areas were sampled south of the main RN 23 highway from Valcheta to Ingeniero Jacobacci (Fig. 2). Roads in this area are nar-row unclassified dirt roads and outcrops are small and sparse.

\section{Western sector}

Exposures south of the town of Ministro Ramos Mexia (Fig. 2) constitute the main area of the Yaminué complex, consisting of both deformed and undeformed granitoids and minor metasedi-mentary rocks.

(1) Arroyo Yaminué, $600 \mathrm{~m}$ north of Puesto Peynecura. VAL004 is a foliated and strongly deformed biotite granodiorite, interlay-ered with pink leucogranite to pegmatite. Rapalini et al. (2013) obtained a U-Pb SHRIMP zircon age of $467 \pm 7$ Ma for granodiorite at this locality. VAL005 is a similar rock from $120 \mathrm{~m}$ to the SW; VAL006 is a $50 \mathrm{~cm}$ pink leucogranite dyke cutting the granodiorite.

(2) Arroyo Yaminué, $7 \mathrm{~km}$ north of Puesto Peynecura. VAL007 is a pink biotite leucogranite sheet interlayered with foliated tonalite-granodiorite VAL008 was originally thought to be equivalent to VAL004, although the foliation is slightly weaker and dips gently to the southwest.

(3) At $30 \mathrm{~km}$ SSE of Ministro Ramos Mexia on the road to Rincón de Treneta. VAL009 is a porphyritic biotite granodiorite with K-feldspar megacrysts $(<4 \mathrm{~cm})$ and a variable foliation that dips up to $38^{\circ} \mathrm{NNE}$. This locality is estimated to be that of sample AB112 of Basei et al. (2002), which gave an upper intersection $\mathrm{U}-\mathrm{Pb}$ age of $305 \pm 31 \mathrm{Ma}$.

\section{Eastern sector}

The area south of the small town of Nahuel Niyeu (Fig. 2) is dominated by the Early Permian Navarrete granite and the Early Palaeozoic meta-sedimentary Nahuel Niyeu Formation, whereas the southwestern part consists of the highly deformed or mylonitized Tardugno Granodiorite, with a probable faulted contact against the latter. Rapalini et al. (2013) reported a U$\mathrm{Pb}$ SHRIMP zircon age of $529 \pm 4 \mathrm{Ma}$ for a sample ascribed to the Tardugno Granodiorite (SA114, see Fig. 2; it should be noted that this age was published as $528.5 \pm 3.5$ $\mathrm{Ma}$.

(1) Arroyo Treneta, $11 \mathrm{~km}$ SSW of Nahuel Niyeu, $5 \mathrm{~km}$ west of Puesto Navarrete. VAL010 is a porphyritic biotite granite with $3 \mathrm{~cm}$ feldspar phenocrysts and strong deformation; effectively an augen-gneiss.
(2) At $9 \mathrm{~km}$ west of Puesto Navarrete, where the road crosses a small tributary of Arroyo Treneta. This is the site from which Basei et al. (2002) obtained a lower intersection age of $300 \pm 6 \mathrm{Ma}$ for a tonalite sample (AB203). The main rock type here is a highly deformed and mylonitized granodiorite, VAL011, which could be a more deformed equivalent to VAL010. However, on the SW corner of the crossing we found a relatively undeformed tonalite, VAL012, which more closely matches the description of the dated sample of Basei et al. (2002).

(3) Samples were taken from the Valcheta pluton in two cuttings on the highway between Nahuel Niyeu and Valcheta: VAL013 and VAL014. VAL 013 is a pink muscovite leuco-monzogranite, which yielded a $\mathrm{K}-\mathrm{Ar}$ age of $449 \pm 7$ Ma (López de Luchi et al. 2008), whereas VAL014 is a medium-grained light grey leucogranite, which has given an Ordovician ${ }^{40} \mathrm{Ar}-{ }^{36} \mathrm{Ar}$ plateau muscovite age of $468 \pm 5 \mathrm{Ma}$ (Rapalini et al. 2013).

\section{Analytical methods}

Geochronological protocols followed those of Pankhurst et al. (2006). Samples were jaw-crushed, sieved to $1 \mathrm{~cm}$ and washed. Zircon was separated at BGS, Keyworth using discmill, super-panner, heavy liquids and magnetic processes. U-Pb ages were obtained on hand-picked zircon mounts using SHRIMP II at the Research School of Earth Sciences, Canberra, where $\mathrm{Hf}$ and oxy-gen isotopes were determined on a selection of dated grains; the former by inductively coupled plasma mass spectrometry (ICP-MS) using a Neptune system (Munizaga et al. 2008) and the latter with SHRIMP II in negative ion mode (Ickert et al. 2008).

A separate aliquot of the washed jaw-crushed material for each sample was further ground to powder for $\mathrm{Rb}-\mathrm{Sr}$ and $\mathrm{Sm}-\mathrm{Nd}$ isotope analyses at Centro de Apoyo a la Investigación de Geocronología y Geoquímica Isotópica, Universidad Complutense de Madrid (UCM) using a VG-Micromass 54 mass spectrometer. $\mathrm{Rb} / \mathrm{Sr}$ ratios were determined by $\mathrm{X}$-ray fluorescence (XRF) at the CAI de Difracción de Rayos X (UCM).

Whole-rock powders prepared in La Plata from unsieved jawcrushed material were sent to ACTLABS, Canada for major and trace element analysis using lithoborate fusion and ICP and ICP-MS methods.

\section{Results}

\section{$\mathrm{U}-\mathrm{Pb}$ zircon dating}

Processed data (Ludwig 2001, 2003) are plotted in Figure 3 . The crystallization ages reported below are quoted at the $95 \%$ confi-dence level, including uncertainty in the calibration. For samples VAL010 and VAL011 it was found possible to correct for common $\mathrm{Pb}$ using the measured ${ }^{204} \mathrm{~Pb}$; for the other samples the ${ }^{238} \mathrm{U} /{ }^{206} \mathrm{~Pb}$ and ${ }^{207} \mathrm{~Pb} /{ }^{206} \mathrm{~Pb}$ ratios were used, so that for these there is no test of discordance.

VAL008. Zircons are mostly clear grains and prismatic needles up to $400 \mu \mathrm{m}$ long with aspect ratios of $3: 1-4: 1$, but the $\mathrm{CL}$ images show that the majority have complex discordant cores, and many show signs of subsequent low-luminescence overgrowths and embayments. Eighteen areas were targeted for analysis (two cores, one overgrowth and 15 zoned rims). The results show low levels of common $\mathrm{Pb}$, with highly variable $U$ contents up to $6600 \mathrm{ppm}$. Ignoring the highest-U area (\#15.1), ${ }^{238} \mathrm{U} /{ }^{206} \mathrm{~Pb}$ ages are in the range $248-256 \mathrm{Ma}$, with a weighted mean of $251 \pm 1 \mathrm{Ma}$, which is taken as the crystallization age of the granodiorite. The overgrowth (Th/ $\mathrm{U}$ $=0.07$ ) shows no significant age difference. 

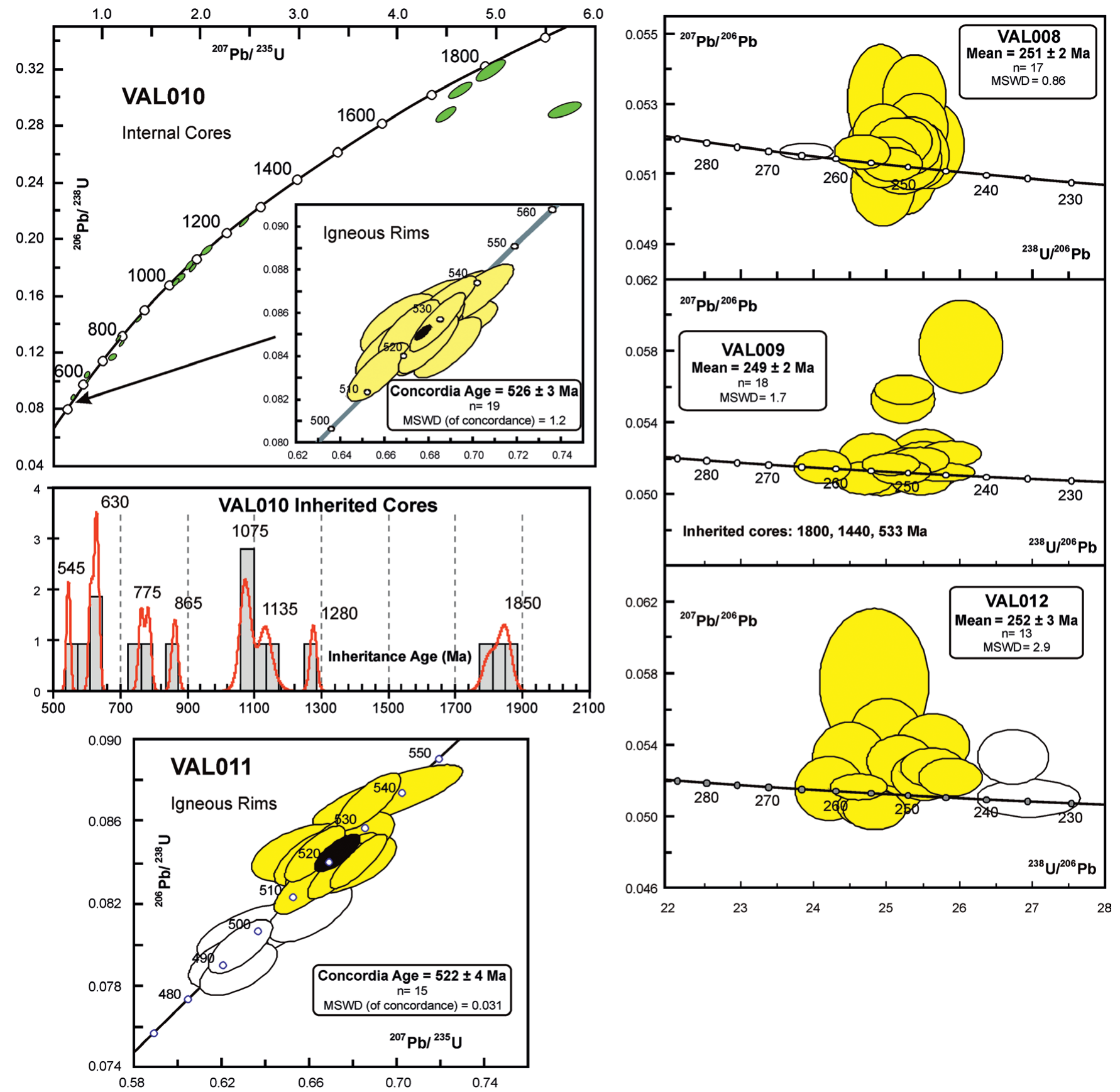

Fig. 3. New SHRIMP U-Pb data for samples from the Tardugno Granodiorite (data corrected for common $\mathrm{Pb}$ using measured ${ }^{204} \mathrm{~Pb}$ ) and Yaminué complex granites (uncorrected data). White ellipses represent data omitted from age calculation.

VAL009. Zircon grains are short pink needles and fragments up to $400 \mu \mathrm{m}$ long and with an aspect ratio of about 3:1. CL images show multistage concentrically zoned crystals with small amounts of met-amorphic overgrowth, especially on fragment terminations. Twenty areas were analysed, including a variety of cores, with $U$ contents up to $1400 \mathrm{ppm}$. Three of the cores gave ${ }^{238} \mathrm{U} /{ }^{206} \mathrm{~Pb}$ ages of 530 , 1440 and $1800 \mathrm{Ma}$, but four others gave ages indistinguishable from the concentrically zoned igneous zircon, in the range 241-255 Ma: these 17 ages have a weighted mean of $249 \pm 2 \mathrm{Ma}$. One overgrowth with low Th/ $\mathrm{U}(0.09)$ gave an anomalous older age of $262 \mathrm{Ma}$.

VAL010. These zircons are short, euhedral, cloudy pink needles with inclusions, typically 150-200 $\mu \mathrm{m}$ long and $100-150 \mu \mathrm{m}$ wide. Concentric zonation is well developed on complex cores, but metamorphic overgrowths are thin or absent. One rim gave a spurious ${ }^{238} \mathrm{U} /{ }^{206} \mathrm{~Pb}$ age of $312 \mathrm{Ma}$ attributable to $\mathrm{Pb}$ loss, whereas those of the remaining 18 (and one core) fall in the range 514-537 Ma, with a weighted mean of $526 \pm 3 \mathrm{Ma}$ (see the concordia (sensu Ludwig 2003) plot of Fig. 3). Several of these areas have $\mathrm{Th} / \mathrm{U}$ ratios $<0.1$ with Th contents of about $50 \mathrm{ppm}$, but oscilla-tory zonation shows that they are magmatic, so that the age is that of emplacement of the granodiorite. Nineteen zircon cores were also analysed, many from grains in which the rims yielded the Cambrian crystallization age. These have normal igneous $U$ and Th contents (typically 350 and 100 ppm, respectively) and yielded ages in the range 528-2260 Ma. A probability plot of these 

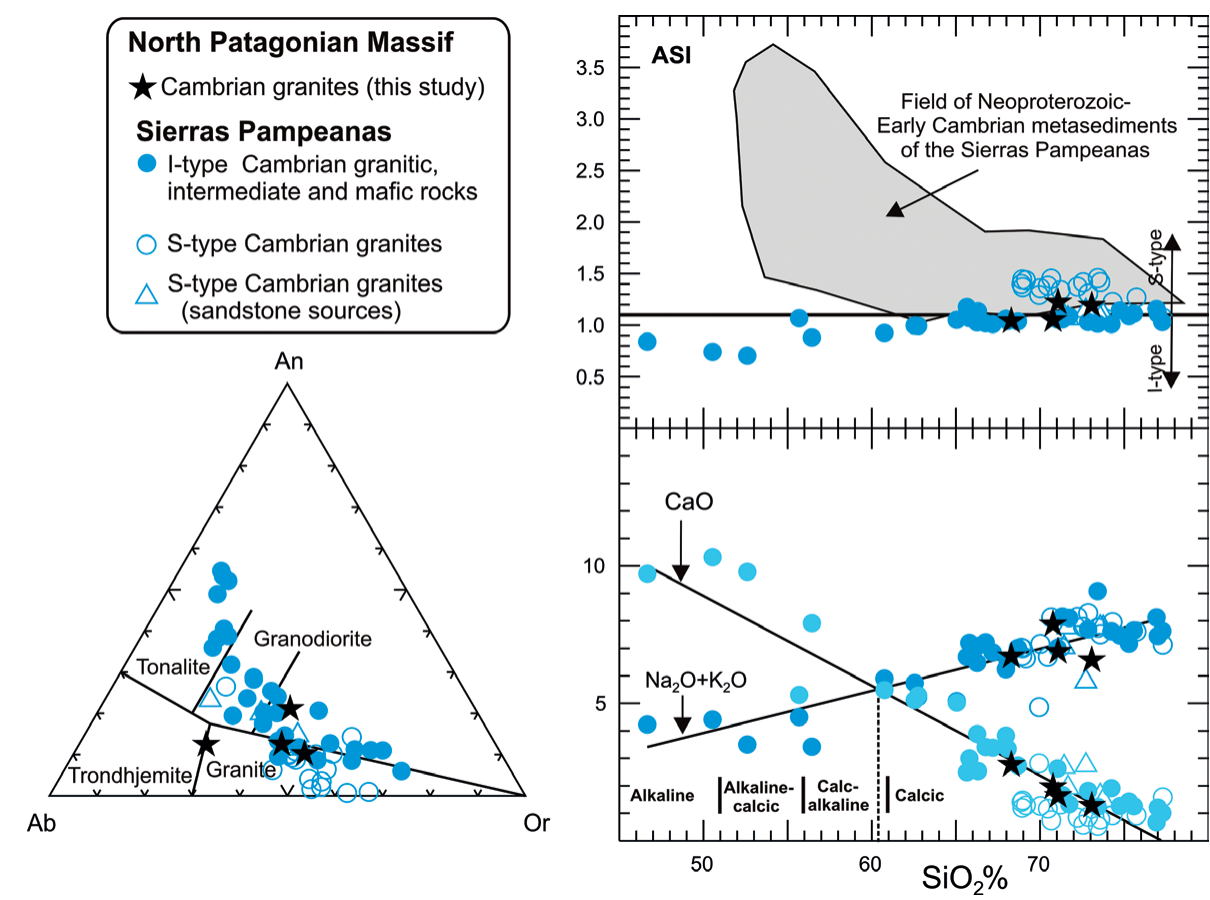

Fig. 4. Major element geochemistry of Cambrian granitoids. Three of the analysed samples of the Tardugno Granodiorite correspond to granites and granodiorites

(one falls close to the trondhjemite field) that are compositionally similar to Cambrian I-type granites and granodiorites of the Sierras Pampeanas. ASI, alumina saturation index (Peacock 1931). inherited core ages is also shown in Figure 3 excluding the oldest, which is strongly discordant.

VAL011. This sample has mostly clear pink prismatic needles 150-200 $\mu \mathrm{m}$ long, some white and turbid, as well as many smaller fragments. The grains show concentric zonation discordant to complex and varied cores, but many are fractured or with inclu-sions, so that only the outer concentric zones were easily targeted for SHRIMP analysis. The 20 areas analysed have similar $U$ and Th contents and ${ }^{238} \mathrm{U}-{ }^{206} \mathrm{~Pb}$ ages to those in the igneous rims of sample VAL010, but with rather more scatter. There is a strong suggestion of bimodality in the age distribution: a group of five gave ages at around $490 \mathrm{Ma}$, which could represent $\mathrm{Pb}$ loss during an Ordovician event, but the remaining 15 analyses yield a con-cordia age of $522 \pm 4 \mathrm{Ma}$, indistinguishable from that of VAL010.

VAL012. Some grains are cracked fragments of pink needles whose original length was mostly $>300 \mu \mathrm{m}$; others are smaller and there are rounded fragments. Concentric zonation is devel-oped on highly discordant and varied cores. Metamorphic over-growths are rare, but many grains are corroded. We analysed 15 clean concentrically zoned outer areas, which had highly variable $\mathrm{U}$ contents (24-1069 ppm) and high Th/U (mostly $>1.0$ ), but which yielded consistent ${ }^{238} \mathrm{U} /{ }^{206} \mathrm{~Pb}$ ages of 238-261 Ma. Ignoring the two youngest ages, which appear to have been affected by some $\mathrm{Pb}$ loss, the weighted mean gives an acceptable crystalliza-tion age of $252 \pm 3 \mathrm{Ma}$.

Implications. These results together with those of Chernicoff et al. (2013) and Rapalini et al. (2013) demonstrate that magmatism in the area was confined in age to c. 520-530 Ma (Cambrian), 470-480 Ma (Ordovician) and 250-280 Ma (Permian). The Early Cam-brian age of the Tardugno Granodiorite is confirmed: the mean of our two ages and that of Rapalini et al. (2013) is $528 \pm 4 \mathrm{Ma}$. The possibility that the Cambrian and Ordovician events could be equivalent to the Pampean (Rapela et al. 1998; lannizzotto et al. 2013) and Famatinian (Pankhurst et al. 1998) magmatic belts of northern and western Argentina is critically assessed here.

\section{Major and trace element geochemistry}

Cambrian granite. Geochemical analyses were obtained for four samples (VAL010 and VAL011 dated here, V10 and V13 previ-ously unpublished); they are classified as granodiorite or granite with $68-73 \% \quad \mathrm{SiO}_{2}$. In alumina saturation and Peacock plots (Fig. 4) they fall on the calcalkaline or calcic trends defined by the c. $530 \mathrm{Ma}$ granitoids of the Eastern Sierras Pampeanas, towards the siliceous end, where there is overlap between pretectonic S-types and post-tectonic I-types. This comparison extends to Harker plots of major and trace elements, such as $\mathrm{CaO}, \mathrm{FeO}, \mathrm{Ga}, \mathrm{Nb}$ and $\mathrm{Zr}$ (not shown); overlap is also apparent with the field of Early Cambrian metasedimentary rocks from the Sierras Pampeanas (e.g. Puncoviscana Formation). As noted above, some of the primary biotite is partly chloritized, but this does not appear to have resulted in major mobility of the alkali metals as the $\mathrm{K}_{2} \mathrm{O}$ average concentration in the Tardugno Grano-diorite is similar to that in the I-type granites of Sierras Pampea-nas: this and the coherent behaviour of immobile elements lead us to believe that the geochemical analyses still closely reflect primary igneous characteristics. Trace element plots show the relative depletion in $\mathrm{Nb}, \mathrm{P}$ and $\mathrm{Ti}$ characteristic of subduction-related magmas (Fig. 5); some Sr depletion is also shown by the Sierras Pampeanas granites (both Itype and S-type with inferred pelitic sources). Low $\mathrm{Nb}$ and $\mathrm{Ga}$ (both $<20 \mathrm{ppm}$ ) clearly distin-guish this plutonic suite from the Late Cambrian peralkaline rhyolites of the Sierra de la Ventana (Rapela et al. 2003), as do the REE patterns (Fig. 6), which are moderately enriched in light REE (LREE), with only a small negative Eu anomaly. They are dissimilar to the more mafic Cambrian granitoids of the El Carancho complex of La Pampa province (Chernicoff et al. 2012), but have strong similarities to Cambrian granites from the Saldania belt of southern Africa (Jordaan et al. 1995; Da Silva et al. 2000; Chemale et al. 2011).

Ordovician granites. Chemical analyses were obtained for sam-ples VAL004 and VAL005 from the outcrop dated at $467 \pm 7$ Ma by Rapalini et al. (2013), and VAL013 and VAL014 from the Val-cheta pluton. In the variation diagrams, the data are plotted for 


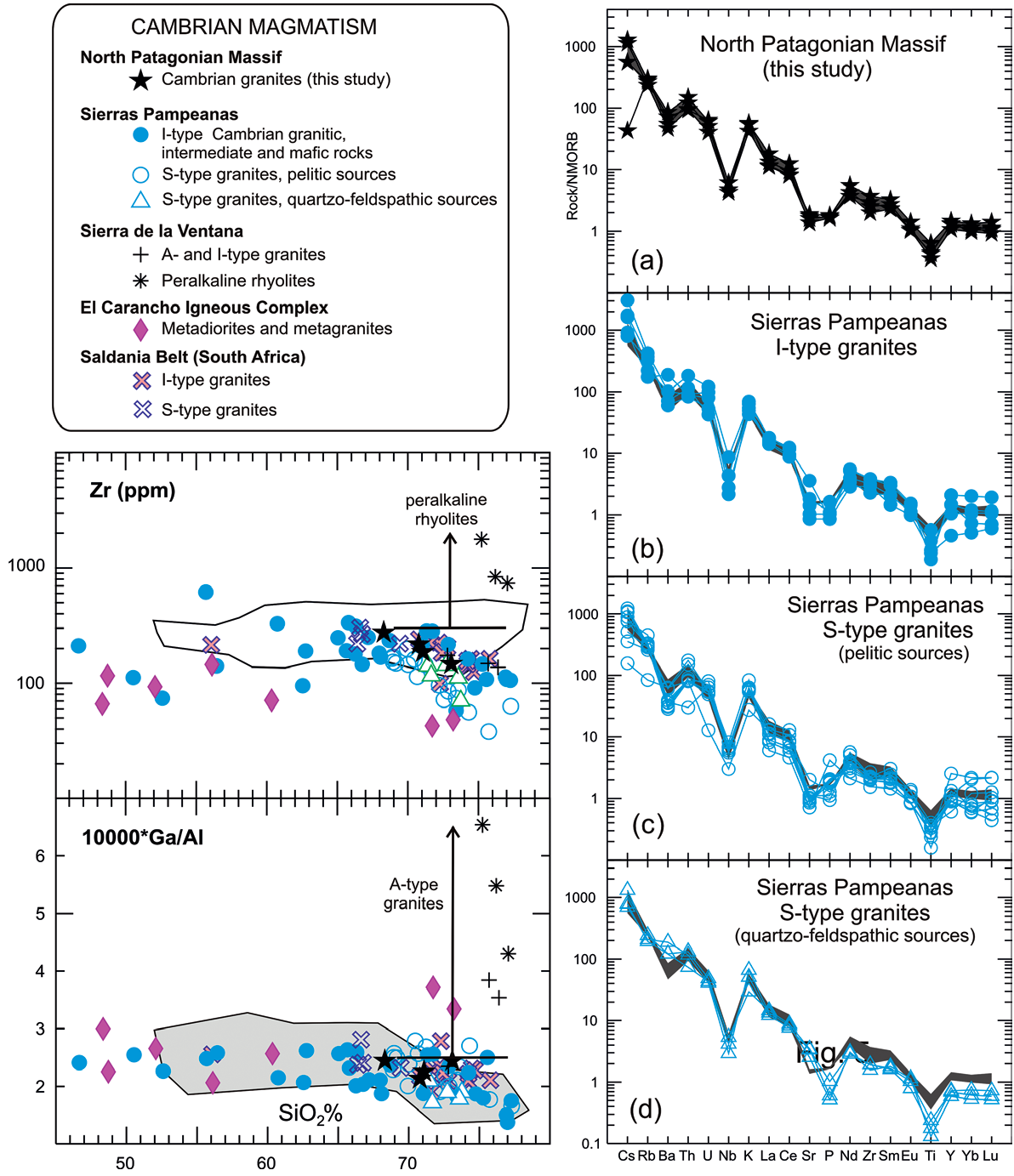

Fig. 5. Trace element plots of Cambrian granitoids. In the trace element spidergrams the field of the Tardugno samples in the top diagram is repeated in the other three. comparison with synchronous Early to Mid-Ordovician granites from the Punta Sierra suite of northeastern Patagonia and Pichi Mahuida in the Río Colorado (Pankhurst et al. 2006), and from the central segment of the Famatinian belt (Pankhurst et al. 1998). Scattered outcrops of Famatinian meta-igneous rocks occur in the south of La Pampa province (around Paso del Bote; see Fig. 1), with $\mathrm{U}-\mathrm{Pb}$ SHRIMP ages of $476 \pm 2 \mathrm{Ma}$ and $466 \pm 4 \mathrm{Ma}$, and a possible metamorphic overprint at $454 \pm 2 \mathrm{Ma}$ (Chernicoff et al. 2010); the geochemical compositions of these rocks are very sim-ilar to those of equivalent rocks of the central segment with the same silica content. Compositions are more calcic than in the Cambrian granitoids (Fig. 7). Casquet et al. (2012) demonstrated the presence of juvenile mafic magmas in the Early Ordovician suites of the Sierras Pampeanas, which thus may be bimodal in both composition and origin, but the Patagonian granites are mostly comparable with the evolved Famatinian I-types.

Permian granites. Chemical analyses were obtained for pink leu-cogranite sheets cutting dated Ordovician and Permian granodior-ites in the southern part of the Yaminué complex as well as the dated undeformed tonalite intruding the Tardugno Granodiorite. They are subalkaline granites, with a more restricted range of silica contents than the Ordovician and Cambrian granitoids (Fig. 8). They also exhibit higher $\mathrm{Sr}, \mathrm{Sr} / \mathrm{Y}, \mathrm{La} /$ $\mathrm{Yb}$ and $\mathrm{Tb} / \mathrm{Yb}$ in the range $60-70 \% \mathrm{SiO}_{2}$. The less siliceous samples have moderately negative $\mathrm{Eu}$ anomalies (Eu/Eu* 0.9-0.7) indicating plagioclase fractionation. Total REE contents are higher in the less evolved rocks. The high $\mathrm{Ga} / \mathrm{Al}$ ratio of $>2$ is transitional from the l-type to the A-type granite field (Whalen et al. 1987).

\section{$\mathrm{Sr}$ and $\mathrm{Nd}$ isotopes}

$\mathrm{Rb}-\mathrm{Sr}$ isotope data are given in Table 1. Initial ${ }^{87} \mathrm{Sr} /{ }^{86} \mathrm{Sr}$ ratios (at $530 \mathrm{Ma}$ ) for the two analysed samples of the Tardugno Granodiorite are distinctly radiogenic, 0.7129 and 0.7104 but fall within the wider range shown by the Cambrian granites of the Sierras Pampeanas (0.7060 0.7237 , with no obvious distinction between pre- and posttectonic plutons, lannizzotto et al. 2013). The $\varepsilon N d t$ values at $530 \mathrm{Ma}$ are -3.7 to -3.0 . Sierras Pampeanas plutons, espeeially the post-tectonic S-types, generally have $\varepsilon N d$ values around

5.5 , but range up to -1.8 ; their crust-derived depleted-mantle model ages range $1400-1700 \mathrm{Ma}$ compared to $1500 \mathrm{Ma}$ for the Tardugno Granodiorite.

$\mathrm{Rb}-\mathrm{Sr}$ and Sm-Nd were obtained for foliated Ordovician gran-ites of the western Yaminué complex (VAL004 and VAL005) and two samples of the undeformed Valcheta granite. Three of the sam-ples have low initial ${ }^{87} \mathrm{Sr} /{ }^{66} \mathrm{Sr}$ of $0.7046-0.7063$ (at $470 \mathrm{Ma}$ ), $\varepsilon N d t$ values of -3.3 to -3.9 and $\mathrm{T}_{\mathrm{DM}} \mathrm{Nd}$ model ages of 1450-1500 Ma. 




Fig. 6. REE plots of Cambrian granitoids, showing the similarity of the Tardugno Granodiorite to the Sierras Pampeanas granites, as distinct from the El Carancho granites (Chernicoff et al. 2012) and the alkaline suites of the Sierra de la Ventana basement (Rapela et al. 2003).



Fig. 7. Geochemistry of Ordovician granitoids. Samples from the Yaminué complex are compared with other Ordovician granitoids from northern Patagonia (the Punta Sierra suite) and Pichi Mahuida and with the large database for the Famatinian granitoids of the Sierras Pampeanas. One sample from the Valcheta pluton is distinguished by its lower $\mathrm{Ba}, \mathrm{Rb}$, LREE and Ti contents, although all fall within the Famatinian composition field.
The fourth sample (VAL013) has a more crustal composition, yielding values of $0.7149,-5.0$ and 1585 $\mathrm{Ma}$, respectively. Thus initial ${ }^{87} \mathrm{Sr} /{ }^{86} \mathrm{Sr}$ ratios are rather lower than the values of $>0.706$ shown by most of the Famatinian granites in the Sierras Pampeanas (Dahlquist et al. 2008) and the Punta Sierra granites of northeastern Patagonia (Pankhurst et al. 2006). However, in terms of $\mathrm{Sm}-\mathrm{Nd}$ isotope systematics (Fig. 9) the Patagonian samples compare well with the I-type Ordovician plutonic rocks from the Sierras Pampeanas (Pankhurst et al. 1998; Dahlquist et al. 2013), especially the later Famatinian granitoids of Sierra de Valle Fértil (Casquet et al. 2012).

Permian igneous rocks from the Yaminué complex also have low to moderate initial ${ }^{87} \mathrm{Sr} /{ }^{86} \mathrm{Sr}$ ratios of $0.7075-$ 0.7097 (the value of 0.7027 for leucogranite vein VAL006 is considered unreliable owing to its high $\mathrm{Rb} / \mathrm{Sr}$ ratio requiring a huge time-correction). Corresponding $\varepsilon N d t$ values at 250 Ala are uniformly low at -5.0 to

8.7, yielding $\mathrm{Nd}$ model ages of c. 1450-1700 Ma. These characteristics are equivalent to those of previously analysed Permian 


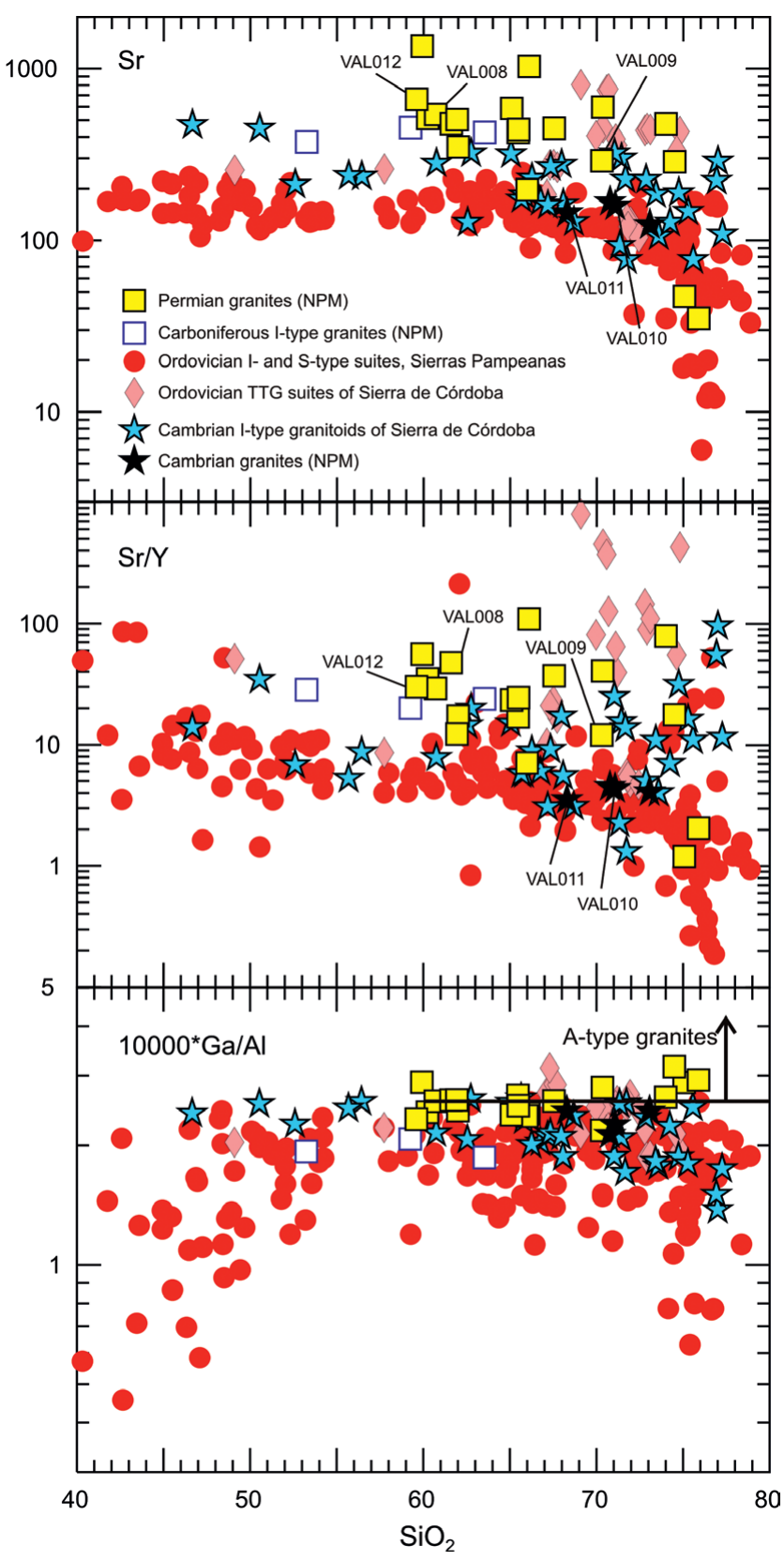

Fig. 8. Geochemistry of Permian granitoids. NPM, North Patagonian Massif.

granites from the North Patagonian Massif (mostly ${ }^{87} \mathrm{Sr} /{ }^{86} \mathrm{Sr}$ $0.7045-0.7085, \varepsilon N d t-2$ to $-10, \mathrm{Nd}$ model ages $1400-1800$ Ma; Fig. 9).

\section{$\mathrm{Hf}$ and $\mathrm{O}$ isotopes in zircon}

Dated zircon grains from one Cambrian and one Permian sample were investigated for $\mathrm{O}$ - and Hf-isotope compositions (Table 2, Fig. 10).

Igneous zircons formed during crystallization of the Tardugno Granodiorite have a well-defined mean $\delta^{18} \mathrm{O}$ value of $+10 \%$, show-ing magma derived from (or heavily contaminated with) pre-exist-ing crustal material. This is confirmed by $\varepsilon \mathrm{Hf}_{t}$ values between +0.2 and -12.6 but concentrated at c. -3.2 . Hf model ages based on derivation from an inferred crustal source indicate separation of the source material from depleted mantle at c. $1600 \mathrm{Ma}$, which is com-parable with the calculated $\mathrm{Nd}$ model age (Fig. 10). With one exception the inherited zircon cores have $\delta^{18} \mathrm{O}$ values $<10 \%$, although only the oldest grain (c. $1840 \mathrm{Ma}$ ) has a value compatible with mantle derivation and one has a low value of $+4.6 \%$ suggest-ing hydrothermal alteration. A crustal origin for most of these inherited zircons is confirmed by $\mathrm{Hf}$ isotope data: Neoproterozoic cores have $\varepsilon \mathrm{Hf}_{\mathrm{t}}$ values of 0 to +5 and crustderived model ages of

\section{c. $1.4 \mathrm{Ga}$; the 'Grenville-age' cores $>1100 \mathrm{Ma}$ have lower $\varepsilon \mathrm{Hf}_{\mathrm{t}}$ and}

model ages of c. $1.8 \mathrm{Ga}$; finally, the two oldest grains with erystal-lization ages of c. $1800 \mathrm{Ma}$ have low $\varepsilon \mathrm{Hf}_{\mathrm{t}}$ values and model ages of 2.4 and $2.7 \mathrm{Ga}$. Only 'Grenville-age' cores $<1100$ Ma have juvenile $\varepsilon \mathrm{Hft}$ of +7.1 and +8.2 , but nevertheless have model ages of $1.3-1.4 \mathrm{Ga}$. These data testify to the presence of continuously recy-cled older crustal material in the source region of the Tardugno Granodiorite.

Zircon in the $250 \mathrm{Ma}$ granite sample VAL009 shows a range of $\delta^{18} \mathrm{O}$ from $+5.8 \%$ o to $+7.8 \%$, which does not overlap with mantle compositions (Fig. 10). $\varepsilon \mathrm{Hf}_{\mathrm{t}}$ values are uniformly and strongly negative $(-7.0$ to -9.2 , with one at -11.4$)$ and crustderived model ages average $1.70 \pm 0.07 \mathrm{Ga}$. Three inherited zircon cores in this sample gave crustal $\delta^{18} \mathrm{O}$ values of +6.5 to $+9.8 \%$, $\varepsilon \mathrm{Hf}_{\mathrm{t}}-2.7$ to +6.3 , and source model ages of $c .1 .4,1.7$ and $2.3 \mathrm{Ga}$. This strong variability, together with the notable difference between the zircon $\mathrm{Hf}$ and whole-rock $\mathrm{Nd}$ model ages (Fig. 10), implies a mixture of old crust and more juvenile material in the source region of the Permian granite. A juvenile component would also be consistent with the occurrence in these rocks of mafic microgranular enclaves and synplutonic diorite dykes as well as two possible stages of crystallization, as suggested by the zonation of plagioclase.

\section{Discussion}

Ages of magmatism in northern Patagonia

$\mathrm{U}-\mathrm{Pb}$ SHRIMP zircon dating has provided a new framework for the interpretation of older data and their reliability. The results pre-sented here, together with those of Pankhurst et al. (2006), Chernicoff et al. (2013) and Rapalini et al. (2013), largely confirm and extend the $\mathrm{Rb}-\mathrm{Sr}$ results of Pankhurst et al. (1992) and the conventional U-Pb data of Varela et al. (2005). They reveal a con-sistent picture of three main periods of Palaeozoic igneous activity in northern and northeastern Patagonia: Cambrian (530-520 Ma), Ordovician (480-465 Ma) and Permian (280-250 Ma). The first two were relatively short-lived, whereas the Permian may be divisible into separate early (c. $280 \mathrm{Ma}$ ) and late (c. 260-250 Ma) phases, the latter extending into the Triassic. Carboniferous magmatism is restricted to the western and southwestern margin of the North Patagonian Massif and is clearly absent from the region bordering the Río Colorado. Earlier multi-grain zircon U-Pb dating by Basei et al. (2002) that suggested ages of c. $300 \mathrm{Ma}$ in the Yaminué and Tardugno areas is best explained by a failure to resolve polygenetic zircon that crystallized in the Early Palaeozoic and late Permian, exemplified by the c. 250 Ma granite with older inheritance within the outcrop of the Cambrian Tardugno Granodiorite.

\section{Magma sources}

Isotope data for the Tardugno Granodiorite $(\mathrm{Sr}$ and $\mathrm{Nd}$ in whole-rocks and $\mathrm{O}$ - and Hf-isotopes in zircon, as well as the $\mathrm{U}-\mathrm{Pb}$ evi-dence of inherited zircon) all indicate that its parent magma contained abundant pre-existing crustal material. The general calc-alkaline geochemistry with relative $\mathrm{Nd}$ and $\mathrm{Ti}$ depletion sug-gests that the primary magma may have been of more primitive 
Table 1. Whole-rock isotope data for Yaminué-Tardugno granitoids

\begin{tabular}{|c|c|c|c|c|c|c|c|c|c|c|c|c|c|}
\hline Sample & $\begin{array}{l}\text { Age } \\
(\mathrm{Ma})\end{array}$ & $\begin{array}{c}\mathrm{Rb} \\
(\mathrm{ppm})\end{array}$ & $\mathrm{Sr}(\mathrm{ppm})$ & ${ }^{87} \mathrm{Rb} /{ }^{86} \mathrm{Sr}$ & ${ }^{87} \mathrm{Sr} /{ }^{86} \mathrm{Sr}$ & $\begin{array}{c}{ }^{87} \mathrm{Sr} /{ }^{86} \mathrm{Sr} \\
\text { (initial) }\end{array}$ & $\begin{array}{c}\mathrm{Sm} \\
(\mathrm{ppm})\end{array}$ & $\begin{array}{c}\mathrm{Nd} \\
(\mathrm{ppm})\end{array}$ & ${ }^{147} \mathrm{Sm} /{ }^{144} \mathrm{Nd}$ & ${ }^{143} \mathrm{Nd} /{ }^{144} \mathrm{Nd}$ & $\begin{array}{c}{ }^{143} \mathrm{Nd} /{ }^{144} \mathrm{Nd} \\
\text { (initial) }\end{array}$ & $\varepsilon \mathrm{Nd}_{\mathrm{t}}$ & $\mathrm{T}_{\mathrm{DM}} *(\mathrm{Ma})$ \\
\hline VAL-010 & 530 & 99 & 75 & 3.827 & 0.74179 & 0.7129 & 7.15 & 31.20 & 0.1385 & 0.512249 & 0.511768 & -3.7 & 1529 \\
\hline VAL-011 & 530 & 105 & 83 & 3.645 & 0.73792 & 0.7104 & 8.57 & 40.30 & 0.1286 & 0.512236 & 0.511789 & -3.2 & 1497 \\
\hline V10 & 530 & & & & & & 6.00 & 27.85 & 0.1302 & 0.512256 & 0.511804 & -3.0 & 1476 \\
\hline VAL-004 & 470 & 109 & 74 & 4.272 & 0.73323 & 0.7046 & 4.07 & 19.90 & 0.1236 & 0.512212 & 0.511831 & -3.9 & 1508 \\
\hline VAL-005 & 470 & 94 & 92 & 2.965 & 0.72616 & 0.7063 & 7.90 & 40.80 & 0.1170 & 0.512197 & 0.511837 & -3.8 & 1499 \\
\hline VAL-013 & 470 & 126 & 46 & 8.029 & 0.76869 & 0.7149 & 0.98 & 3.40 & 0.1742 & 0.512315 & 0.511779 & -5.0 & 1584 \\
\hline VAL-014 & 470 & 141 & 102 & 4.020 & 0.73161 & 0.7047 & 3.37 & 12.30 & 0.1656 & 0.512375 & 0.511865 & -3.3 & 1458 \\
\hline VAL-006 & 250 & 125 & 67 & 5.416 & 0.72199 & 0.7027 & 4.26 & 13.00 & 0.1981 & 0.512279 & 0.511955 & -7.1 & 1585 \\
\hline VAL-007 & 250 & 111 & 165 & 1.955 & 0.71509 & 0.7081 & 6.16 & 32.30 & 0.1153 & 0.512158 & 0.511969 & -6.8 & 1565 \\
\hline VAL-008 & 250 & 102 & 359 & 0.823 & 0.71136 & 0.7084 & 4.89 & 34.00 & 0.0869 & 0.512014 & 0.511871 & -8.7 & 1699 \\
\hline VAL-009 & 250 & 109 & 138 & 2.300 & 0.71563 & 0.7075 & 7.93 & 42.20 & 0.1136 & 0.512247 & 0.512061 & -5.0 & 1434 \\
\hline VAL-012 & 250 & 124 & 545 & 0.660 & 0.71201 & 0.7097 & 7.56 & 43.80 & 0.1043 & 0.512151 & 0.511981 & -6.6 & 1549 \\
\hline
\end{tabular}

$\mathrm{Rb}$ and $\mathrm{Sr}$ determined by XRF, and isotope ratios determined by mass spectrometry, Universidad Complutense, Madrid. Sm and Nd data from ACTLABS.

${ }^{*} \mathrm{Nd}$ model age calculated for crustal precursor (DePaolo et al. 1991).

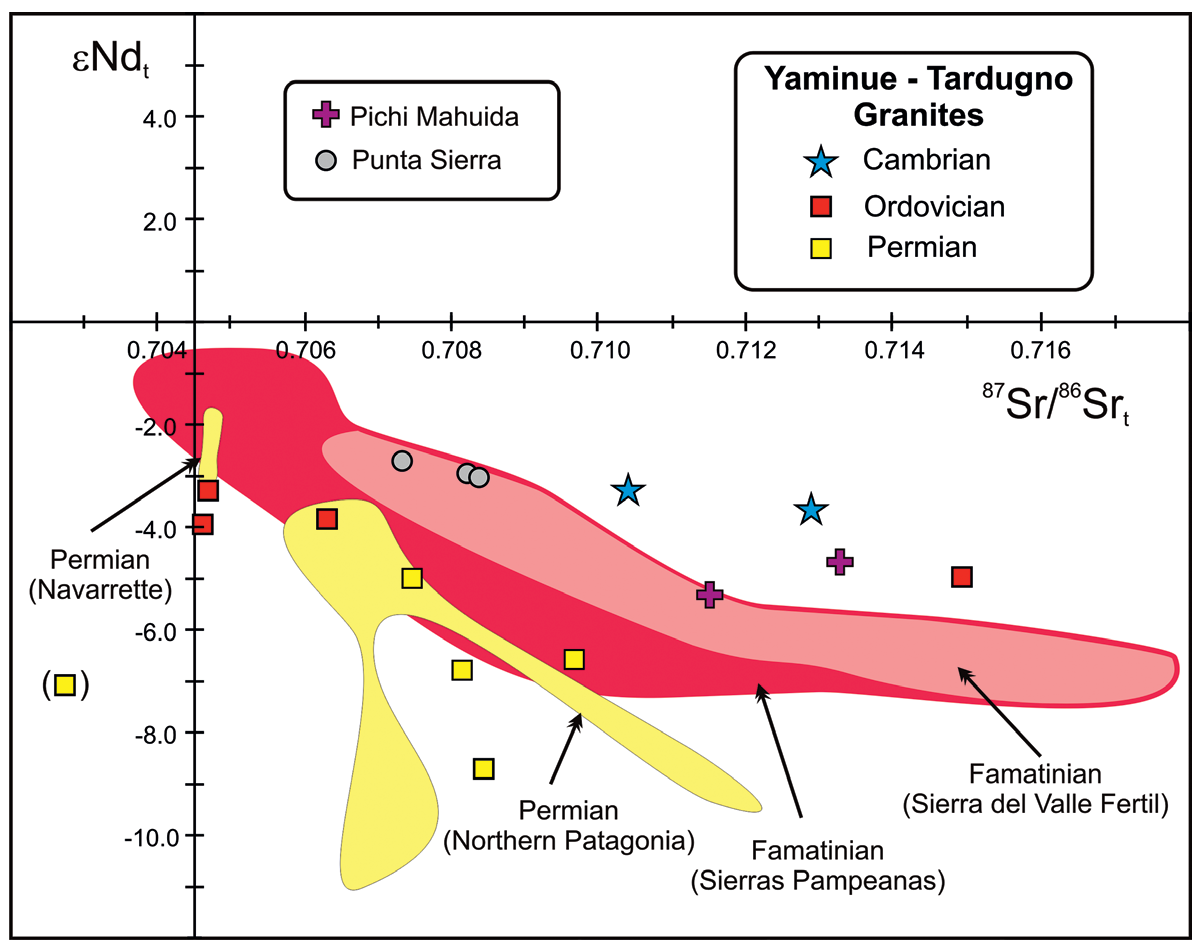

Fig. 9. Sr-Nd isotope plot (after Pankhurst et al. 2006). subduction-related composition, but the preservation of pre-emplacement zircon cores shows that the magma temperature dur-ing their incorporation did not exceed that at which such cores would either melt or become isotopically equilibrated. The $\mathrm{U}-\mathrm{Pb}$ ages of these incorporated zircons (Fig. 4) include elements of 'Brasiliano' (c. $630 \mathrm{Ma}$ ) and 'Grenville' (900-1300 $\mathrm{Ma}$ ) and scarce Palaeoproterozoic (c. $1850 \mathrm{Ma}$ ) material; two Cambrian cores dated at $545 \pm 6$ and $528 \pm$ $7 \mathrm{Ma}$, the latter indistinguishable from the coexisting igneous rim age, may represent local isotopic homogenization. Because the Th/ $\mathrm{U}$ ratios and $\mathrm{O}$ - and $\mathrm{Hf}$ isotope data indicate that the incorporated zircons were mostly igneous but all of crustal provenance, the source of this material was almost certainly an Eocambrian or late Neoproterozoic mature sediment or metasediment representing poly-recycled Gondwana-margin material in the upper crust. The correspondence between whole-rock $\mathrm{Nd}$ model ages of 1450-1500 Ma and the c. $1400 \mathrm{Ma}$
$\mathrm{Hf}$ model ages of many of the analysed zircons suggests an ulti-mate origin from a crustal reservoir of this age, but the $1850 \mathrm{Ma}$ inherited zircon cores show that even older material contributed to the magma source.

Genesis of the Ordovician magmatism of Patagonia is less clear, as there are as yet no dedicated studies of inherited zircon and no zircon O- or Hf-isotope data. The existing $\mathrm{U}-\mathrm{Pb}$ dating and whole-rock element and isotope geochemistry support the involvement of upper crustal anatexis for the Early Ordovician magmatism of the Sierras Pampeanas, the Pichi Mahuida and Punta Sierra suites of northern Patagonia (Pankhurst et al. 2006). The geochemistry of the Ordovician granite of Puesto Peynecura in the Yaminué com-plex cannot be distinguished from this general pattern.

The Permian granites in the Yaminué complex share geochemi-cal and isotope characteristics with previously dated Permian igne-ous rocks of northern Patagonia, again demonstrating a major 
Table 2. Oxygen and hafnium isotope data from zircon spot analyses

\begin{tabular}{|c|c|c|c|c|c|c|c|c|c|c|}
\hline Spot ID & Age (Ma) & \pm & ${ }^{18} \mathrm{O} /{ }^{16} \mathrm{O}$ & $\delta^{18} \mathrm{O} \%$ & ${ }^{176} \mathrm{Hf} /{ }^{177} \mathrm{Hf}$ & $\pm\left(10^{-6}\right)$ & ${ }^{176} \mathrm{Lu} /{ }^{177} \mathrm{Hf}$ & $\varepsilon \mathrm{Hf}_{\mathrm{t}}$ & $2 \sigma$ & $\mathrm{T}_{\mathrm{DM}}(\mathrm{Ga})$ \\
\hline \multicolumn{11}{|l|}{ VAL009 } \\
\hline 1.1 & 249 & 3 & 0.002039 & 6.2 & 0.282434 & 21 & 0.00065 & -7.0 & 0.7 & 1.63 \\
\hline 1.2 & 1344 & 17 & 0.002047 & 9.8 & 0.282131 & 23 & 0.00094 & 6.3 & 0.8 & 1.66 \\
\hline 3.1 & 256 & 3 & 0.002040 & 6.7 & 0.282428 & 36 & 0.00106 & -7.1 & 1.3 & 1.64 \\
\hline 4.1 & 247 & 3 & 0.002041 & 7.0 & 0.282312 & 28 & 0.00074 & -11.4 & 1.0 & 1.90 \\
\hline 5.1 & 248 & 3 & 0.002040 & 6.5 & 0.282419 & 27 & 0.00083 & -7.6 & 1.0 & 1.67 \\
\hline 6.1 & 244 & 3 & 0.002040 & 6.5 & 0.282422 & 26 & 0.00096 & -7.6 & 0.9 & 1.66 \\
\hline 7.1 & 253 & 3 & 0.002039 & 6.3 & 0.282378 & 34 & 0.00108 & -8.9 & 1.2 & 1.76 \\
\hline 8.1 & 248 & 3 & 0.002039 & 6.0 & 0.282388 & 28 & 0.00085 & -8.7 & 1.0 & 1.74 \\
\hline 9.1 & 250 & 3 & 0.002038 & 5.8 & 0.282401 & 25 & 0.00127 & -8.2 & 0.9 & 1.71 \\
\hline 9.2 & 251 & 3 & 0.002040 & 6.5 & 0.282387 & 31 & 0.00180 & -8.8 & 1.1 & 1.75 \\
\hline 10.1 & 249 & 3 & 0.002040 & 6.4 & 0.282432 & 34 & 0.00142 & -7.2 & 1.2 & 1.64 \\
\hline 11.1 & 254 & 3 & 0.002038 & 5.8 & 0.282400 & 30 & 0.00074 & -8.1 & 1.1 & 1.70 \\
\hline 13.1 & 245 & 3 & 0.002039 & 6.0 & 0.282430 & 28 & 0.00050 & -7.2 & 1.0 & 1.64 \\
\hline 14.1 & 249 & 3 & 0.002040 & 6.4 & 0.282419 & 29 & 0.00097 & -7.6 & 1.0 & 1.67 \\
\hline 15.1 & 252 & 3 & 0.002039 & 6.2 & 0.282434 & 32 & 0.00103 & -7.0 & 1.1 & 1.63 \\
\hline 16.1 & 247 & 3 & 0.002042 & 7.8 & 0.282392 & 28 & 0.00081 & -8.5 & 1.0 & 1.73 \\
\hline 17.1 & 520 & 5 & 0.002042 & 7.6 & 0.282483 & 27 & 0.00078 & 0.6 & 1.0 & 1.37 \\
\hline 18.1 & 1459 & 30 & 0.002040 & 6.5 & 0.281810 & 68 & 0.00102 & -2.7 & 2.4 & 2.32 \\
\hline 19.1 & 247 & 3 & 0.002042 & 7.6 & 0.282378 & 30 & 0.00152 & -9.2 & 1.1 & 1.77 \\
\hline \multicolumn{11}{|l|}{$V A L 010$} \\
\hline 1.1 & 524 & 5 & 0.002048 & 10.4 & 0.282403 & 25 & 0.00230 & -2.6 & 0.9 & 1.57 \\
\hline 5.1 & 528 & 5 & 0.002047 & 10.0 & 0.282229 & 38 & 0.00175 & -8.5 & 1.3 & 1.95 \\
\hline 5.2 & 1842 & 21 & 0.002038 & 5.7 & 0.281509 & 28 & 0.00053 & -4.2 & 1.0 & 2.72 \\
\hline $8.1 \mathrm{~b}$ & 523 & 6 & 0.002047 & 10.2 & 0.282368 & 26 & 0.00183 & -3.7 & 0.9 & 1.64 \\
\hline 8.2 & 1800 & 19 & 0.002039 & 6.1 & 0.281683 & 36 & 0.00096 & 0.5 & 1.3 & 2.39 \\
\hline 9.1 & 526 & 6 & 0.002046 & 9.3 & 0.282105 & 41 & 0.00066 & -12.6 & 1.5 & 2.20 \\
\hline 11.1 & 523 & 5 & 0.002049 & 10.8 & 0.282406 & 34 & 0.00216 & -2.5 & 1.2 & 1.57 \\
\hline 11.2 & 1069 & 13 & 0.002043 & 7.8 & 0.282375 & 38 & 0.00178 & 8.2 & 1.3 & 1.32 \\
\hline 12.1 & 522 & 5 & 0.002048 & 10.4 & 0.282377 & 43 & 0.00282 & -3.8 & 1.5 & 1.65 \\
\hline 12.2 & 863 & 9 & 0.002036 & 4.6 & 0.282422 & 49 & 0.00249 & 5.0 & 1.7 & 1.36 \\
\hline 15.1 & 529 & 5 & 0.002047 & 10.2 & 0.282406 & 35 & 0.00293 & -2.6 & 1.2 & 1.58 \\
\hline 18.1 & 523 & 5 & 0.002048 & 10.4 & 0.282374 & 31 & 0.00209 & -3.6 & 1.1 & 1.64 \\
\hline 18.2 & 783 & 8 & 0.002045 & 8.9 & 0.282375 & 30 & 0.00104 & 2.5 & 1.1 & 1.46 \\
\hline 19.1 & 527 & 5 & 0.002046 & 9.5 & 0.282476 & 100 & 0.00190 & 0.2 & 3.5 & 1.40 \\
\hline 22.1 & 1079 & 17 & 0.002047 & 10.1 & 0.282338 & 66 & 0.00179 & 7.1 & 2.3 & 1.40 \\
\hline 24.1 & 1276 & 10 & 0.002039 & 6.1 & 0.282087 & 28 & 0.00097 & 3.1 & 1.0 & 1.80 \\
\hline 25.1 & 626 & 6 & 0.002044 & 8.5 & 0.282416 & 37 & 0.00105 & 0.5 & 1.3 & 1.46 \\
\hline 26.1 & 1138 & 26 & 0.002042 & 7.6 & 0.282080 & 28 & 0.00068 & 0.1 & 1.0 & 1.89 \\
\hline 28.1 & 612 & 6 & 0.002042 & 7.8 & 0.282414 & 30 & 0.00116 & 0.1 & 1.1 & 1.47 \\
\hline
\end{tabular}

Oxygen isotope ratios $( \pm 0.025 \%)$ normalized relative to $\mathrm{FC} 1=5.4 \%$. ${ }^{176} \mathrm{Lu}$ decay constant of $\left.1.865 \times 10^{-11}(\mathrm{Söderlund} \mathrm{et} \mathrm{al.} 2004).\right){ }^{176} \mathrm{Hf} /{ }^{177} \mathrm{Hf}$ and ${ }^{176} \mathrm{Lu} /{ }^{177} \mathrm{Hf}$ of CHUR values of 0.282785 and 0.0336 (Bouvier et al. 2008). ) Depleted mantle values: ${ }^{176} \mathrm{Hf} /{ }^{177} \mathrm{Hf}=0.283225 \mathrm{and}{ }^{176} \mathrm{Lu} /{ }^{177} \mathrm{Hf}=0.0385(\mathrm{Vervoort} \&$ Blichert-Toft 1999); Bulk Earth ${ }^{176} \mathrm{Lu} /{ }^{177} \mathrm{Hf}=0.015$ (Goodge \& Vervoort 2006).) $\mathrm{T}_{\mathrm{DM}}$ ages are two-stage calculated values.

crustal component, albeit with some juvenile contribution. As noted above, the few zircon cores analysed show similar inherit-ance to the Cambrian plutonism, back to at least c. $1800 \mathrm{Ma}$. Chernicoff et al. (2013) analysed a 260 Ma Permian gneissic gran-ite in the Yaminué complex that contained significant Archaean inheritance (cores U-Pb dated at 2600-2700 Ma; Hf model ages for both Permian and inherited zircon consistently in the range 1900-3900 Ma); in contrast, they did not find Archaean provenance in biotite schist from the Yaminué complex (mostly Palaeozoic, espe-cially Ordovician). We have found no indications of Archaean inheritance in our samples of the Permian granites (and only a sin-gle zircon $\mathrm{Hf}$ model age of $2700 \mathrm{Ma}$ in the Cambrian Tardugno Granodiorite), although several $\mathrm{Hf}$ model ages fall in the range 1900-2400 Ma, which could in principle suggest derivation from Palaeoproterozoic or older crust. The Permo-Triassic granites from northern Patagonia analysed by Pankhurst et al. (2006) have whole-rock Nd model ages of 1230-1800 Ma; Hf model ages for emplace-ment-age zircons in these rocks are consistently 1000-1600 Ma (Fanning et al. 2011) and the oldest inherited zircon so far dated is $1800 \mathrm{Ma}$, although there has been no comprehensive study of

zircon cores. The discrepancy between our data and those of Chernicoff et al. (2013) from an outcrop apparently less than $5 \mathrm{~km}$ away is not easy to explain unless the Permian magmas were derived from extremely heterogeneous source material. The asso-ciation of strongly negative $\varepsilon \mathrm{Ndt}$ values with relatively low initial ${ }^{87} \mathrm{Sr} /{ }^{86} \mathrm{Sr}$ ratios compared with the Cambrian and Ordovician plu-tons (Fig. 9), as well as high $\mathrm{Sr}$ and high $\mathrm{Sr} / \mathrm{Y}$ ratios (Fig. 8), sug-gests that the source of the Permian magmas had relatively low $\mathrm{Rb} / \mathrm{Sr}$ ratios (or high $\mathrm{Sr}$ contents), a characteristic normally associated with higher-grade metamorphic rocks and hence deeper crustal 

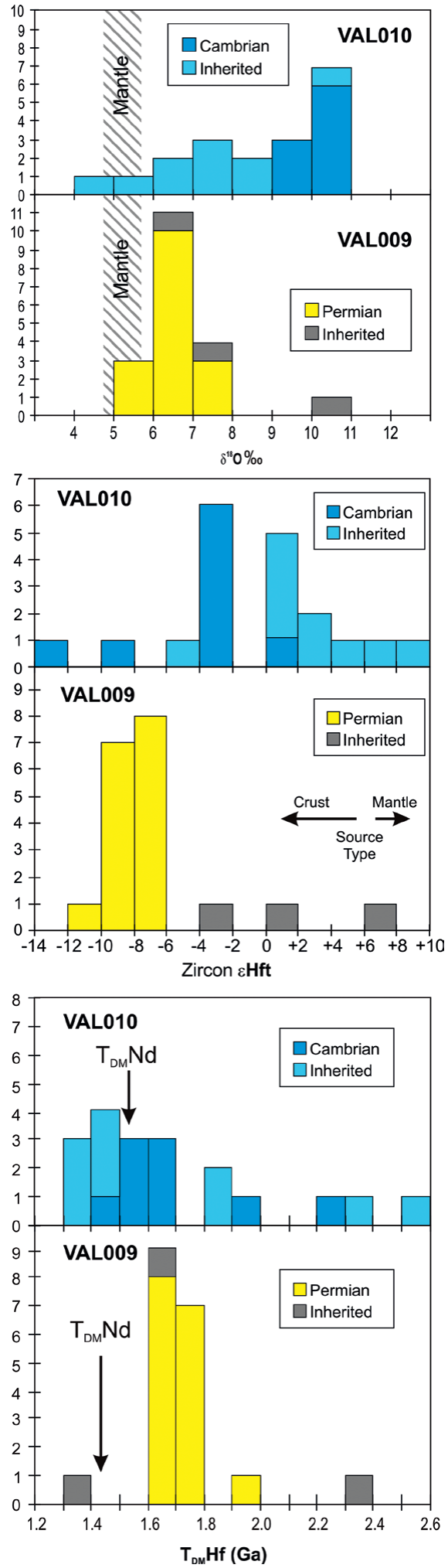

Fig. 10. Oxygen and $\mathrm{Hf}$ isotope geochemistry of dated zircon grains from the Tardugno Granodiorite (VAL010) and a Permian granite from the Yaminué complex (VAL009). Most zircon was derived from older crust. In the lower plot the crustal residence time of the zircon is estimated assuming extraction at the time of the $\mathrm{U}-\mathrm{Pb}$ ages from crust with ${ }^{176} \mathrm{Lu} /{ }^{177} \mathrm{Hf}=0.015$; these ages are compared with the two-stage whole-rock $\mathrm{T}_{\mathrm{DM}} \mathrm{Nd}$ ages for the two granite samples; the discrepancy in the case of the Permian granite suggests mixed sources with different zircon contributions. levels. Comparatively high Ga/Al ratios (Fig. 8) are usually ascribed to granulitic residues remaining in the lower crust (Whalen et al. 1987). These features, which persist into the Mesozoic magmatism, are compatible with magma genesis through widespread partial melting of the lower crust of the North Patagonian Massif, ascribed by Pankhurst et al. (2006) to slab break-off and subsequent asthenospheric mantle upwelling.

\section{Sediment deposition}

Detrital zircon ages were determined for samples from the western outcrops of the Early Palaeozoic Nahuel Niyeu Formation by Pankhurst et al. (2006) and Rapalini et al. (2013); a provenance pattern combining both SHRIMP datasets is shown in Figure 11. This shows a dominant peak at $526 \mathrm{Ma}$ (the maximum age of sedimentation), a minor one at $635 \mathrm{Ma}$ and a broader one at c. $1040 \mathrm{Ma}$, corresponding to Pampean, Brasiliano and 'Grenville' orogenies respectively, with very rare older input indicated by single zircon ages. The other main metasedimentary unit of NE Patagonia, the El Jagüelito Formation, has essentially the same provenance pattern (Pankhurst et al. 2006). The main peak is indistinguishable from the age of the Tardugno Granodiorite, strongly suggesting that equivalent local basement rocks were the main source of the sedimentary detritus. The slight 'shoulder' at the younger end of the pattern is due to three grains dated at $480-500 \mathrm{Ma}$, but we do not think these are sufficiently robust to indicate Ordovician deposition as claimed by Chernicoff et al. (2013); a Late Cambrian age still seems probable. The provenance is not, however, diagnostic for the location of the sedimentary basin, as these three orogenies (in varying degrees) are the main contributors to Middle to Late Cambrian sediments in the Sierras Pampeanas (Augustssohn et al. 2011; Steenken et al. 2011) and the upper Byrd Group of the Transantarctic Mountains (Goodge et al. 2004).

\section{Correlation of Early Palaeozoic magmatism}

The isolated exposures of Early Palaeozoic granitic rocks in the North Patagonian Massif are important to the reconstruction of the proto-Gondwana margin. Their times of emplacement and geochemical, isotopic and tectonic signatures need to be tested for possible connections to known magmatic belts in South America, South Africa and Antarctica.

A comparison of the chronology of Cambrian magmatism in southwestern Gondwana is shown in Figure 12. The closest comparisons for the Tardugno Granodiorite are with the Pampean granites of the Sierras Pampeanas (pre-deformation granite $537 \pm 4$ Ma; post-deformational granite $530 \pm 4 \mathrm{Ma}$ ), the basement of the Sierra de la Ventana (524-531 Ma; Rapela et al. 2003) and the basement granitoids beneath the Magallanes basin of southernmost Patagonia $(529 \pm 8,521 \pm 4,538 \pm 6,523 \pm 7,522 \pm 4,521 \pm 6 \mathrm{Ma}$; Söllner et al. 2000; Pankhurst et al. 2003; Hervé et al. 2010). The latter in turn may be correlated with Cambrian granites in the Saldania belt of South Africa (summary by Chemale et al. 2011), where early S-type granites (550-527 Ma) are followed by I-type granites (540-530 Ma) and then post-tectonic A-type granites (530-500 Ma). We have shown that the major and trace element characteristics of the Tardugno Granodiorite are of mixed (heavily contaminated) I-type, which might correspond to the main phase of I-type granites in the Saldania belt. As yet there are no geochemical studies or Hf-in-zircon isotope data for the Sierra de la Ventana or Magallanes base-ment granites.

A compilation of ages for Ross magmatism in the central Transantarctic Mountains made by Goodge et al. (2012) shows a wide range of ages (Fig. 12) among which the oldest are for foliated 


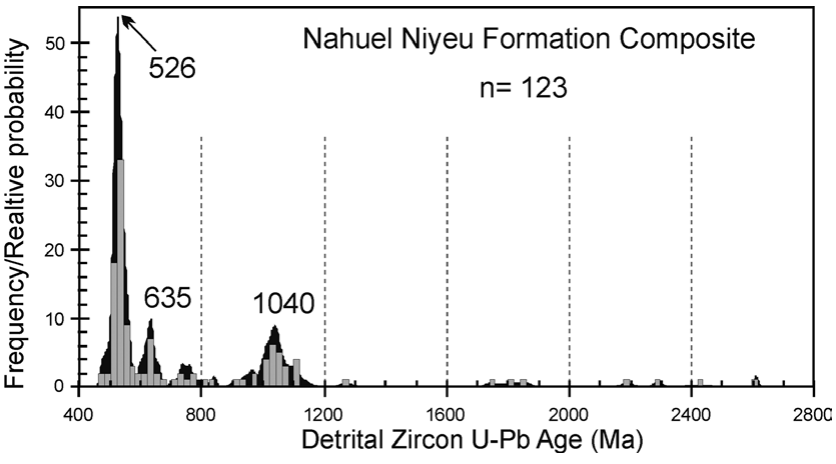

Fig. 11. Composite provenance pattern (U-Pb ages of detrital zircon) of Nahuel Niyeu Formation (Pankhurst et al. 2006;

Rapalini et al. 2013). Data were filtered to remove discordant analyses $(>15 \%)$ and two ages $<460$ Ma that are inconsistent with field relations.

bodies at c. $550 \mathrm{Ma}$ (in one case $589 \pm 5 \mathrm{Ma}$ ), and a single pegmatite dated at $524 \pm 5 \mathrm{Ma}$. There is a strongly defined peak at $490 \mathrm{Ma}$ for the main post-tectonic granites, which does not coincide either with the c. $528 \mathrm{Ma}$ Tardugno Granodiorite or, as pointed out by Rapalini et al. (2013), with the undeformed Ordovician granites of the 470-480 Ma Punta Sierra suite of Patagonia. More extensive $\mathrm{U}-\mathrm{Pb}$ dat-ing than is currently available could show that the magmatic history of any of the areas considered here is more extended in time, but at present neither Cambrian nor Ordovician granites of northern Patagonia seem to be synchronous with any stage of Ross orogeny magmatism in the central Transantarctic Mountains.

\section{Conclusions: evidence for and against allochthonous Patagonia}

(1) There is no evidence for pre-collisional subduction magmatism in northern Patagonia that could be related to Carboniferous ocean closure to the north. Ramos (2008) proposed an active arc from 310 to $285 \mathrm{Ma}$, and Ramos \& Naipauer (2012) enlarged this range to 395-300 Ma; there are no igneous rocks of such ages anywhere in northeastern Patagonia near the Río Colorado and the only known Devonian-Carboniferous granitoids occur west of the North Patagonian Massif in the proto-Andean margin. The only remaining conceivable candidate for a pre-collisional magmatic arc in northern Patagonia would be the earliest Permian (281 \pm 3 Ma) Navarrete granite (Figs 2 and 8). However, there are several strong arguments against this possibility, as follows.

(a) The granite in its type area close to the Tardugno Granodiorite is essentially undeformed.

(b) The granite $(281 \pm 3 \mathrm{Ma})$ was essentially synchronous with ash-beds in the Tunas Formation (uppermost Sierra de la Ventana sequence), dated by SHRIMP at $282 \pm 3 \mathrm{Ma}$ (Tohver et al. 2008) and $281 \pm 2$ Ma (López-Gamundí et al. 2013). According to palaeomag-netic evidence, the Tunas Formation underwent folding contempo-raneous with deposition (Tomezzoli \& Vilas 1999), suggesting that by the time the Navarrete pluton was emplaced, deformation of the Sierra de la Ventana sequence was well under way.

(c) Choyoi Group volcanic rocks at San Rafael (Fig. 1) also show extended Permian magmatism: an early andesitic stage at $282 \pm 3 \mathrm{Ma}$ and later rhyolitic episodes at $265 \pm 1 \mathrm{Ma}$ and $252 \pm 3 \mathrm{Ma}$ (Rocha-Campos et al. 2011); that is, the same timing as plutonism in the North Patagonian Massif. However, occurring more than $500 \mathrm{~km}$ north, Choiyoi volcanism cannot be related to continental collision along the Río Colorado corridor. Moreover, the relatively short period from 280 to c. 260 Ma that would be available for

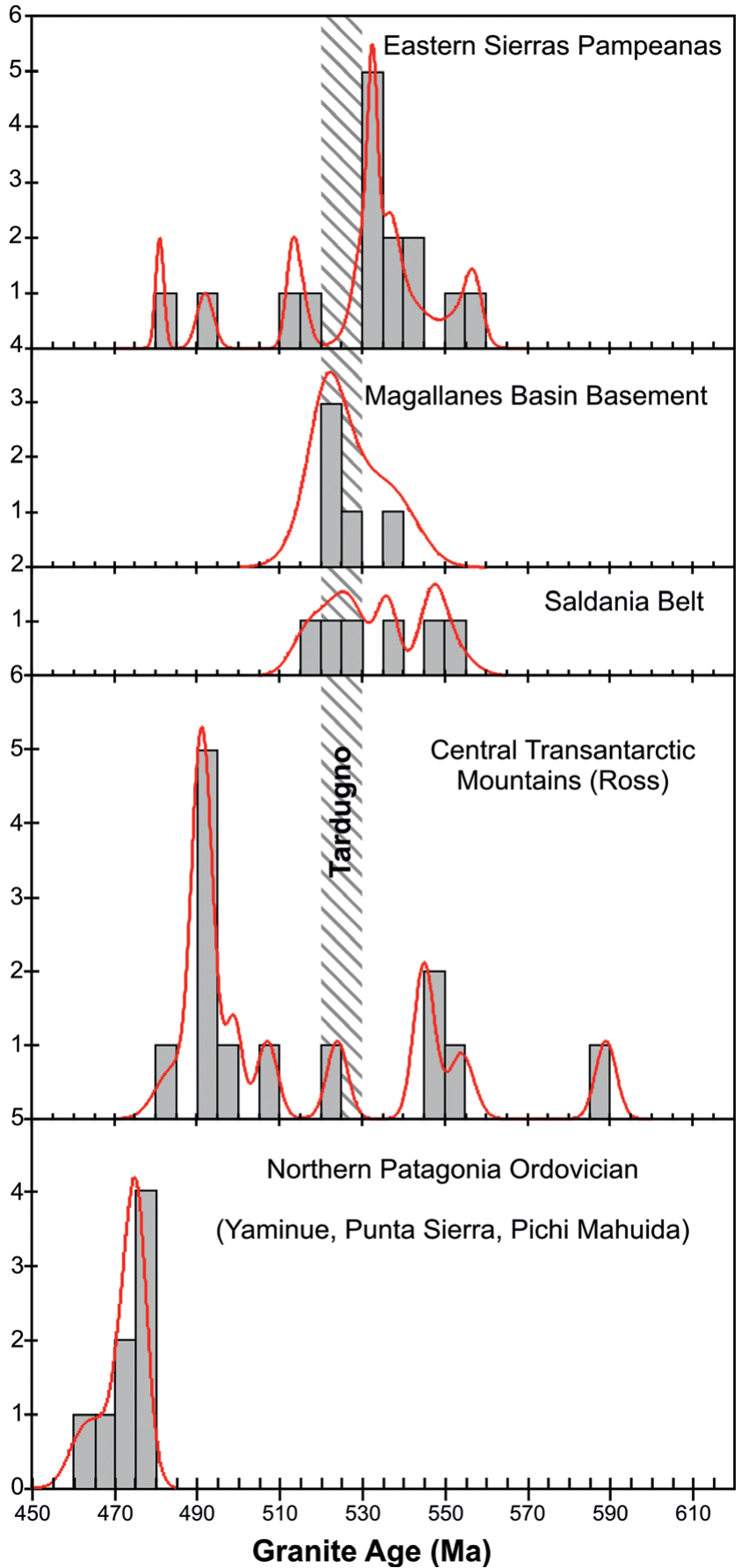

Fig. 12. Comparison of precise U-Pb granite chronology of northern Patagonia with Cambrian granites in the Sierras Pampeanas, the Magallanes basin basement of Tierra del Fuego, the Saldania belt of southern Africa, and the Ross orogen of the Central Transantarctic Mountains. The last of these also encompasses part of the Early Ordovician, albeit at $490 \mathrm{Ma}$, which is not typical of the South American Ordovician granites.

pre-collisional subduction is not consistent with the closure of a major ocean necessary for the translation of Patagonia from the Central Transantarctic region throughout the Early Palaeozoic. Mafic microgranular enclaves and synplutonic dioritic dykes in the Late Permian granitoids of the Valcheta-Yaminué area suggest hybridization of acid and mafic magmas, the juvenile magmatic 
component perhaps being indicative of the heat source that triggered melting of the lower crust.

(2) The Navarrete granite cuts, and shows a contact aureole against, the deformed Nahuel Niyeu metasedimentary rocks of the SW-vergent thrust sheets described by von Gosen (2003). Within the present study area, rocks mapped as Nahuel Niyeu Formation are intruded by the essentially undeformed Ordovician Valcheta pluton. Metamorphism and deformation here are therefore prePermian in age, probably pre- $470 \mathrm{Ma}$, and cannot be synchronous with NNE-vergent folding in the Sierra de la Ventana. Similar relationships are found in the Punta Sierra area, where the c. $470 \mathrm{Ma}$ unmetamorphosed Punta Sierra granites intrude El Jagüelito Formation metasediments, and metamorphic zircon rims in the Mina Gonzalito amphibolite-grade granite gneiss (to the SE of our study area) were dated at $472 \pm 5 \mathrm{Ma}$ (Fig. 1; see Pankhurst et al.

2006).

(3) On the other hand, whereas the $281 \pm 3$ Ma Navarette granite in the Tardugno area appears to be post-deformational, the younger Permian granites of the Yaminué complex (c. $250 \mathrm{Ma}$ ) are strongly foliated and form shallow NE-dipping sheets that could be inter-preted as due to thrusting towards the SW (López de Luchi et al. 2010). Deformation occurred at high temperature, possible with a later lower temperature reactivation. The complex local variations in deformational style and timing remain unexplained in detail but suggest a picture of heterogeneous deformation along the NE mar-gin of the North Patagonian Massif at various times including the Late Permian. Provisionally, this could be seen as resulting from readjustment between different crustal domains during compres-sive deformation contemporaneous with crustal melting. Local response to deformation may also be enhanced by thinned crust in northern Patagonia inherited from the Late Cambrian rifting epi-sode recorded in the Sierra de la Ventana basement (see below and Rapela et al. 2003).

(4) The Late Permian NE-vergent fold-and-thrust belt of the Sierra de la Ventana is strong evidence for a crust-shortening event. Detailed geophysical study of the offshore extension of the Colorado basin (Fig. 1) by Pángaro \& Ramos (2013) shows the fold belt continuing for at least $600 \mathrm{~km}$ along strike, where they postulated a large area of pre-Permian strata with no detectable Late Palaeozoic deformation. This lack of deformation is interpreted as due to northward displacement of the orogenic front on a regional detachment thrust, in a similar way to the occurrence of undeformed Cretaceous strata between the Jura Mountains and the highgrade deformed Alps. However, in the latter case, associated with a major continent-continent collision, the maximum width of this displacement zone over the pre-existing European basement is $c$. $100 \mathrm{~km}$ (e.g. Sommaruga 1999), whereas in the present case it would need to be $c .400 \mathrm{~km}$, and the basement is unknown. It is also necessary to assume that the collision of an allochthonous Patagonia terrane was equally responsible for deformation of the Cape Fold Belt of South Africa and the Ellsworth Mountains of Antarctica (see Curtis 2001). Such a tectonic model has not yet been devel-oped, and would also need to accommodate the probability that the Antarctic Peninsula was close to southern Africa in Late Carboniferous time (Bradshaw et al. 2012). On the other hand, Dalziel et al. (2000) argued that the fold belt may have formed through the interaction of a mantle plume with a distant subduction zone, without the need for any continental collision.

(5) From chronological, geochemical and isotopic points of view, the Cambrian and Ordovician granites of northern Patagonia could be regarded as representing continuity of the Pampean and Famatinian belts of the Sierras Pampeanas through Patagonia as part of the Early Palaeozoic margin of Gondwana, as previously proposed by Rapela \& Pankhurst (2002), Pankhurst et al. (2003),
Gregori et al. (2008) and Rapalini et al. (2013). However, Late Cambrian (510 Ma) alkaline volcanism in the basement rocks of the Sierra de la Ventana was interpreted as representing rifting and the possible separation of a southern block (Rapela et al. 2003). If the margin remained essentially continuous through the Early Palaeozoic, this would probably be better interpreted as intra-continental rifting without the opening of a major ocean. Some tectonic readjustment must have occurred, as the Cambrian Tardugno Granodiorite is now found to the west of the Ordovician Punta Sierra granite suite (the opposite sense to the relationship between the Pampean and Famatinian belts of the Sierras Pampeanas). A curved continental margin in NE Patagonia may be one way to resolve this problem (Rapalini et al. 2013).

(6) The occurrence of fossil archaeocyathids in limestone blocks within the post-535 Ma El Jagüelito Formation of northeastern Patagonia has been interpreted as evidence of juxtaposition against the Central Transantarctic Mountains (González et al. 2011), and the Ordovician granites of the former region have been suggested as correlatives of Ross magmatism in the latter. However, the geochronological comparisons made here (Fig. 12) do not support this magmatic correlation. Perhaps further discoveries will revise the extent of this Australo-Antarctica faunal realm.

(7) The presence of detrital Archaean zircon grains in the metasedimentary rocks of the Yaminué complex (and in a Permian granite that intrudes them) demonstrated by Chernicoff et al. (2013) has not been substantiated by the present work: the oldest age of inheritance observed in both Cambrian and Permian samples is $c$. $1850 \mathrm{Ma}$. A single Archaean Hf model age was obtained from one zircon grain in the Cambrian Tardugno Granodiorite; as in previous studies of Pampean and Famatinian granites, the predominant $\mathrm{Nd}$ and $\mathrm{Hf}$ model ages presented here are Mesoproterozoic or late Palaeoproterozoic (1.1-2.0 Ma), which is consistent with the exposed and inferred basement geology of southern South America (e.g. Martínez Dopico et al. 2011).

The various lines of evidence discussed in this paper point to an origin of the North Patagonian Massif as a crustal block genetically related to, and probably structurally continuous with, the South American crustal blocks to the north from Early Palaeozoic time, as previously maintained by other researchers (e.g. Rapalini et al. 2013). Overall, we regard the case for the origin of Patagonia as a far-travelled allochthonous block as doubtful, if not yet finally resolved. The observed geology would be equally explicable in terms of crustal shortening across the junction between parautochthonous blocks, without the closure of a major ocean. The data presented here provide a strong factual basis for future refinement of the evolution of northern Patagonia.

R.J.P. gratefully acknowledges a Fermor Fund grant from the Geological Society of London. Other funding for this work was through ANPCyT grant PICT 0956 (to S. Geuna), University of Buenos Aires grant 100597 to A.E.R., CONICET grant PIP1940 to C.W.R., and Spanish MICINN grant CGL2009-07984 (to C.G.). The authors thank E. G. Baldo and C. Martínez Dopico for help in the initial stages of this work, and J. Goodge for sharing unpublished data. P. Cawood and B. Murphy supplied helpful comments in review.

\section{References}

Augustssohn, C., Rüsing, T., et al 2011. Detrital quartz and zircon combined: The production of mature sand with short transportation paths along the Cambrian West Gondwana margin, northwestern Argentina. Journal of Sedimentary Research, 81, 284-298.

Basei, M.A.S., Varela, R., Sato, A.M., Siga, O., Jr. \& Llambías, E.J. 2002. Geocronología sobre rocas del Complejo Yaminué, Macizo Norpatagónico, Río Negro, Argentina. In: CABAleRI, N.G., CingolanI, C.A., ET AL. (eds) 15th Congreso Geológico Argentino, Actas III. 117-122. 
BOUVIER, A., VERVOORT, J.D. \& PATCHETT, P.J. 2008. The Lu-Hf and Sm-Nd isotopic composition of CHUR: constraints from unequilibrated chondrites and implications for the bulk composition of terrestrial planets. Earth and Planetary Science Letters, 273, 48-57.

BRADSHAW, J.D., VAUGHAN, A.P.M., MILLAR, I.L., FLOWERDEW, M.J., TROUW, R.A.J., FANNING, C.M. \& WHITEHOUSE, M.J. 2012. Permo-Carboniferous conglomerates in the Trinity Peninsula Group at View Point, Antarctic Peninsula: Sedimentology, geochronology and isotope evidence for prov-enance Peninsula: Sedimentology, geochronology and isotope evidence for prov-
and tectonic setting in Gondwana. Geological Magazine, 149, 626-644.

CAMINOS, R., CHERNICOFF, C. \& VARELA, R. 1994. Evolución tectónico-metamórfica y edad del Complejo Yaminué, Basamento pre-andino norpa-tagónico, República Argentina. In: CAMPOS, E. \& CECIONI, A. (eds) 7th Congreso Geológico Chileno, Tomo II, Universidad del Norte Chile, Departamento de Geociencias, Facultad de Ciencias. Antofagasta, Chile, 1301-1305.

CASQUET, C., RAPELA, C.W., PANKHURST, R.J., BALDO, E.G., GALINDO, C FANNING, C.M. \& DAHLQUIST, J. 2012. Fast sediment underplating and essentially coeval juvenile arc magmatism in the Ordovician continental margin of Gondwana, Western Sierras Pampeanas, Argentina. Gondwana Research, 22, $664-673$.

CAWOOD, P.A. 2005. Terra Australis Orogen: Rodinia breakup and development of the Pacific and lapetus margins of Gondwana during the Neoproterozoic and Paleozoic. Earth-Science Reviews, 69, 249-279.

CHEMALE, F., SCHEEPERS, R., GRESSE, P.G. \& VAN SCHMUS, W.R.

${ }^{2011}$ Geochronology and sources of late Neoproterozoic to Cambrian granites of the Saldania Belt. International Journal of Earth Sciences, 100, 431-444.

CHERNICOFF, C.J. \& CAMINOS, R. 1996. Estructura y metamorfismo del Complejo Yaminué, Macizo Norpatagónico oriental, provincia de Rio Negro. Revista de la Asociación Geológica Argentina, 51, 107-118.

CHERNICOFF, C.J. \& ZAPPETTINI, E.O. 2004. Geophysical evidence for terrane boundaries in South-Central Argentina. Gondwana Research, 7, 1105-1116.

CHERNICOFF, C.J., ZAPPETTINI, E.O., SANTOS, J.O.S., ALLCHURCH, S. \& MCNAUGHTON, N.J. 2010. The southern segment of the Famatinian magmatic arc, La Pampa Province, Argentina. Gondwana Research, 4, 662675.

CHERNICOFF, C.J., ZAPPETTINI, E.O., SANTOS, J.O.S., GODEAS, M.C., BELOUSOVA E. \& MCNAUGHTON, N.J. 2012. Identification and isotopic studies of early Cambrian magmatism (EI Carancho Igneous Complex) at the boundary between Pampia terrane and the Río de la Plata craton, La Pampa province, Argentina. Gondwana Research, 21, 378-393.

CHERNICOFF, C.J., ZAPPETTINI, E.O., SANTOS, J.O.S., MCNAUGHTON, N.J. \& BELOUSOVA, E. 2013. Combined U-Pb SHRIMP and Hf isotope study of the Late Paleozoic Yaminué Complex, Río Negro province, Argentina: Implications for the origin and evolution of the Patagonia composite ter-rane. Geoscience Frontiers, 4, 37-56.

CURTIS, M.J. 2001. Tectonic history of the Ellsworth Mountains, West Antarctica: Reconciling a Gondwana enigma. Geological Society of America Bulletin 113, 939-958

DAHLQUIST, J.A., PANKHURST, R.J., ET AL. 2008. New SHRIMP U-Pb data from the Famatina Complex: Constraining Early-Mid-Ordovician Famatinian mag-matism in the Sierras Pampeanas, Argentina. Geologica Acta, 6, 319-333.

DAHLQUIST, J.A., PANKHURST, R.J., ET AL. 2013. Hf and Nd isotopes in Early Ordovician to Early Carboniferous granites as monitors of crustal growth in the Proto-Andean margin of Gondwana. Gondwana Research, 23,1617-1630.

DALLA SALDA, L.H., CINGOLANI, C.A. \& VARELA, R. 1992. Early Paleozoic belt of the Andes in southwestern South America: result of Laurentia-Gondwana collision? Geology, 20, 617-620.

DALZIEL, I.W.D., LAWVER, L.A. \& MURPHY, J.B. 2000. Plumes, orogenesis and supercontinental fragmentation. Earth and Planetary Science Letters, 178, 1-11.

DA SILVA, L.C., GRESSE, P.G., SCHEEPERS, R., MCNAUGHTON, N.J., HARTMANN L.A. \& FLETCHER, I. 2000. U-Pb SHRIMP and Sm-Nd age constraints on the timing and sources of the Pan-African Cape Granite Suite, South Africa. Journal of African Earth Sciences, 30, 795-815.

DEPAOLO, D.J., LINN, A.M. \& SCHUBERT, G. 1991. The continental crustal age distribution: methods of determining mantle separation ages from $\mathrm{Sm}-\mathrm{Nd}$ iso-topic data and application to the Southwestern U.S. Journal of Geophysical Research, 96B, 2071-2088.

FANNING, C.M., HERVÉ, F., PANKHURST, R.J., RAPELA, C.W., KLEIMAN, L.E., YAXLEY, G.M. \& CASTILLO, P. 2011. Lu-Hf isotope evidence for the prov-enance of Permian detritus in accretionary complexes of western Patagonia and the Antarctic Peninsula region. Journal of South American Earth Sciences, 32, $485-496$

GONZÁLEZ, P.D., TORTELLO, M.F. \& DAMBORENEA, S.E. 2011. Early Cambrian archeocyathan limestone blocks in low-grade meta-conglomerate from El Jaguelito Formation (Sierra Grande, Río Negro, Argentina). Geologica Acta, 9, 159-173.
GOODGE, J.W. \& VERVOORT, J.D. 2006. Origin of Mesoproterozoic A-type granites in Laurentia: $\mathrm{Hf}$ isotope evidence. Earth and Planetary Sciences Letters, 243, 711-731.

GOODGE, J.W., WILLIAMS, I.S. \& MYROW, P. 2004. Provenance of Neoproterozoic and lower Paleozoic siliciclastic rocks of the central Ross orogen, Antarctica: detrital record of rift-, passive-, and active-margin sedimenta-tion. Geological Society of America Bulletin, 116, 1253-1279.

GOODGE, J.W., MARK FANNING, C., NORMAN, M.D. \& BENNETT, V.C. 2012 Temporal, isotopic and spatial relations of Early Paleozoic Gondwana-margin arc magmatism, Central Transantarctic Mountains, Antarctica. Journal of arc magmatism, Central Transantarctic Mountain
Petrology, http://dx.doi.org/10.1093/petrology/egs043.

GOZALVEZ, M.R. 2009. Petrografía y edad ${ }^{40} \mathrm{Ar} /{ }^{39} \mathrm{Ar}$ de leucogranitos peraluminosos al oeste de Valcheta, Macizo Norpatagónico (Río Negro). Revista de la Asociación Geológica Argentina, 64, 183-359.

GREGORI, D.A., KOSTADINOFF, J., STRAZZERE, L. \& RANIOLO, A. 2008. Tectonic significance and consequences of the Gondwanide orogeny in northern Patagonia, Argentina. Gondwana Research, 14, 429-450.

HARRINGTON, H.J. 1972. Sierras Australes de Buenos Aires. In: LEANZA, A.F. (ed.) Geología Regional Argentina. Academia Nacional de Ciencias, Córdoba, Argentina, 395-405.

HERVÉ, F., CALDERÓN, M., FANNING, C.M., KRAUS, S. \& PANKHURST, R.J. 2010. SHRIMP chronology of the Magallanes Basin basement, Tierra del Fuego: Cambrian plutonism and Permian high-grade metamorphism. Andean Geology, 37, 253-275.

IANNIZZOTTO, N.F., RAPELA, C.W., BALDO, E.G.A., GALINDO, C., FANNING, C.M. \& PANKHURST, R.J. 2013. The Sierra Norte-Ambargasta Batholith: late Ediacaran-Early Cambrian magmatism associated with Pampean transpres-sional tectonics. Journal of South American Earth Sciences, 42, 127-143.

ICKERT, R.B., HIESS, J., ET AL. 2008. Determining high precision, in situ, oxygen isotope ratios with a SHRIMP II: analyses of MPI-DING silicate-glass ref-erence materials and zircon from contrasting granites. Chemical Geology, 257, 114-128.

JORDAAN, L.J., SCHEEPERS, R. \& BARTON, E.S. 1995. The geochemistry and isotopic composition of the mafic and intermediate igneous components of the Cape Granite Suite, South Africa. Journal of African Earth Sciences, 21, 59-70.

KAY, S.M., RAMOS, V.A., MPODOZIS, C. \& SRUOGA, P. 1989. Late Paleozoic to Jurassic silicic magmatism at the Gondwana margin: Analogy to the Middle Proterozoic in North America? Geology, 17, 324-328.

KOSTADINOFF, J., GREGORI, D.A. \& RANIOLO, A. 2005. Configuración geofísicageológica del sector norte de la provincia de Río Negro. Revista de la Asociación Geológica Argentina, 60, 368-376.

LÓPEZ DE LUCHI, M.G., WEMMER, K. \& RAPALINI, A.E. 2008. The cooling history of the North Patagonian Massif: First results for the granitoids of the Valcheta area, Río Negro, Argentina (Abstract). In: 6th South American Symposium on Isotope Geology, San Carlos de Bariloche, Argentina [CD edition].

LÓPEZ DE LUCHI, M., RAPALINI, A.E. \& TOMEZZOLI, R.N. 2010. Magnetic fabric and microstructures of Late Paleozoic granitoids from the North Patagonian Massif: Evidence of a collision between Patagonia and Gondwana? Tectonophysics, 494, 118-137.

LÓPEZ-GAMUNDÍ, O., FILDANI, A., WEISLOGEL, A. \& ROSSELLO, E. 2013. The age of the Tunas formation in the Sauce Grande basin-Ventana foldbelt (Argentina): Implications for the Permian evolution of the southwest-ern margin of Gondwana. Journal of South American Earth Sciences, 45, 250-258.

LUDWIG, K.R. 2001. SQUID 1.02, A User's Manual. Berkeley Geochronology Center Special Publication, 2.

LUDWIG, K.R. 2003. Isoplot/ExVersion 3.0: a geochronological toolkit for Microsoft Excel. Berkeley Geochronology Center Special Publication, 4. MARTíNEZ DOPICO, C., LOPEZ DE LUCHI, M., RAPALINI, A.E. \& KLEINHANNS, I.C. 2011. Crustal segments in the North Patagonian Massif, Patagonia: An inte-grated perspective based on $\mathrm{Sm} / \mathrm{Nd}$ isotope systematics. Journal of South American Earth Sciences, 31, 324-341.

MUNIZAGA, F., MAKSAEV V., FANNING, C.M., GIGLIO, S., YAXLEY, G. \& TASSINARI, C.C.G. 2008. Late Paleozoic-Early Triassic magmatism on the west-ern margin of Gondwana: Collahuasi area, Northern Chile. Gondwana Research, 13, 407-427.

PÁNGARO, F. \& RAMOS, V.A. 2013. Paleozoic crustal blocks of onshore and offshore central Argentina: New pieces of the southwestern Gondwana collage and their role in the accretion of Patagonia and the evolution of Mesozoic South Atlantic sedimentary basins. Marine and Petroleum Geology, http://dx.doi.org/10.1016/ j.marpetgeo.2012.05.010.

PANKHURST, R.J., RAPELA, C.W., CAMINOS, R., LLAMBÍAS, E.J. \& PÁRICA, C. 1992. A revised age for the granites of the central Somuncura batholith, North Patagonian Massif. Journal of South American Earth Sciences, 5, 321-325.

PANKHURST, R.J., RAPELA, C.W, SAAVEDRA, J., BALDO, E., DAHLQUIST, J, PASCUA, I. \& FANNING, C.M. 1998. The Famatinian magmatic arc in the souther 
Sierras Pampeanas. In: PANKHURST, R.J. \& RAPELA, C.W. (eds) The ProtoAndean Margin of Gondwana. Geological Society, London, Special Publications, 142, 343-367.

PANKHURST, R.J., RAPELA, C.W., LOSKE, W.P., FANNING, C.M. \& MÁRQUEZ, M. 2003. Chronological study of the pre-Permian basement rocks of southern Patagonia. Journal of South American Earth Sciences, 16, 27-44. PANKHURST,

R.J., RAPELA, C.W., FANNING, C.M. \& MÁRQUEZ, M. 2006.

Gondwanide continental collision and the origin of Patagonia. Earth-Science Reviews, 76, 235-257.

PASSCHIER, C.W. \& TROUW, R.A.J. 2005. Microtectonics. Springer, Berlin. PEACOCK,

M.A. 1931. Classification of igneous rock series. Journal of Geology,

39, 54-67.

RAMOS, V.A. 1984. Patagonia: ¿Un continente paleozoico a la deriva? In: NULLO, F.E., CINGOLANI, C., ET AL. (eds) IX Congreso Geológico Argentino Actas 2. Asociación Geológica Argentina, Buenos Aires, 311-325.

RAMOS, V.A. 2008. Patagonia: A Paleozoic continent adrift? Journal of South American Earth Sciences, 26, 235-251.

RAMOS, V.A. \& NAIPAUER, M. 2012. Patagonia: un terreno alóctono acrecionado al Gondwana Occidental y su contribución a la formación de los paleoAndes en el Paleozoico superior. In: FERNÁNDEZ, L.P., FERNÁNDEZ, A., ET AL. (eds) VIII Congreso Geológico de España, Geo-Temas 13, Oviedo, Spain. 1903-1906 [CD Edition].

RAPALINI, A.E. 2005. The accretionary history of southern South America from the latest Proterozoic to the Late Palaeozoic: Some palaeomagnetic con-straints. In: VAUGHAN, A.P.M., LEAT, P.T. \& PANKHURST, R.J. (eds) Terrane Processes at the Margins of Gondwana. Geological Society, London, Special at the Margins of Gond

RAPALINI, A.E., LOPEZ DE LUCHI, M., MARTINEZ DOPICO, C., LINCE KLINGER, F., GIMENEZ, M.E. \& MARTINEZ, M.P. 2010. Did Patagonia collide against Gondwana in the Late Paleozoic? Some insights from a multidisciplinary study of magmatic units of the North Patagonian Massif. Geologica Acta, 8, 349-371.

RAPALINI, A.E., LÓPEZ DE LUCHI, M., TOHVER, E. \& CAWOOD, P.A. 2013. The South American ancestry of the North Patagonian Massif: Geochronological evi-dence for an autochthonous origin? Terra Nova, 25, 337-342, http://dx.doi. org/10.1111/ ter.12043.

RAPELA, C.W. \& LLAMBÍAS, E.J. 1985. Evolución magmática y relaciones regionales de los complejos eruptiovos de La Esperanza, provincia de Río Negro. Revista de la Asociación Geológica Argentina, 40, 4-25.

RAPELA, C.W. \& PANKHURST, R.J. 2002. Eventos tecto-magmáticos del Paleozoico Inferior en el Margen Proto-Atlántico del Sur de Sudamérica. In: CABALERI, N., CINGOLANI, C.A., ET AL. (eds) XV Congreso Geológico Argentino, Actas, Tomo 1. Asociación Geológica Argentina, Buenos Aires, 24-29.

RAPELA, C.W., PANKHURST, R.J., CASQUET, C., BALDO, E., SAAVEDRA, J., GALINDO, C \& FANNING, C.M. 1998. The Pampean orogeny of the southern proto-Andes: Cambrian continental collision in the Sierras de Córdoba. In: PANKHURST, R.J. \& RAPELA, C.W. (eds) The Proto-Andean Margin of Gondwana. Geological Society, London, Special Publications, 142, 181-217.
RAPELA, C.W., PANKHURST, R.J., FANNING, C.M. \& GRECCO, L.E. 2003. Basement evolution of the Sierra de la Ventana Fold Belt: New evidence for Cambrian continental rifting along the southern margin of Gondwana. Journal of the Geological Society, London, 160, 613-628.

ROCHA-CAMPOS, A.C., BASEI, M.A., ET AL. 2011. 30 million years of Permian volcanism recorded in the Choiyoi igneous province (W Argentina) and their source for younger ash fall deposits in the Paraná Basin: SHRIMP U-Pb zircon geochronology evidence. Gondwana Research, 19, 509-523.

SÖDERLUND, U., PATCHETT, J.P., VERVOORT, J.D. \& ISACHSEN, C.E. 2004. The 176 Lu decay constant determined by $\mathrm{Lu}-\mathrm{Hf}$ and $\mathrm{U}-\mathrm{Pb}$ isotope systematics of Precambrian mafic intrusions. Earth and Planetary Sciences Letters, 219, 311-324.

Söllner, F., Miller, H. \& Hervé, M. 2000. An Early Cambrian granodiorite age from the pre-Andean basement of Tierra del Fuego (Chile): The missing link between South America and Antarctica? Journal of South American Earth Sciences, 13, 163-177.

SOMMARUGA, A. 1999. Décollement tectonics in the Jura foreland fold-and-thrust belt. Marine and Petroleum Geology, 16, 111-134

STEENKEN, A., LÓPEZ DE LUCHI, M.G., MARTÍNEZ DOPICO, C., DROBE, M., WEMMER, K. \& SIEGESMUND, S. 2011. The Neoproterozoic-early Paleozoic metamorphic and magmatic evolution of the Eastern Sierras Pampeanas: an overview. International Journal of Earth Sciences, 100, 465488.

TOHVER, E., CAWOOD, P.A., ROSSELLO, E., LOPEZ DE LUCHI, M.G., RAPALINI, A \& JOURDAN, F. 2008. New SHRIMP U-Pb and $40 \mathrm{Ar} / 39 \mathrm{Ar}$ constraints on the crustal stabilization of southern South America, from the margin of the Rio de Plata Geophysical Union, Fall Meeting, T23C-2052.

TOMEZZOLI, R.N. \& VILAS, J.F. 1999. Palaeomagnetic constraints on the age of deformation of the Sierras Australes thrust and fold belt, Argentina. Geophysical Journal International, 138, 857-870.

VARELA, R., DALLA SALDA, L., CINGOLANI C. \& GÓMEZ, V. 1991. Estructura, petrología y geocronología del basamento de la región del Limay, provin-cias de Río Negro y Neuquen, Argentina. Revista Geológica de Chile, 18, 147-163.

VARELA, R., BASEI, M.A.S., CINGOLANI, C.A., SIGA, O., Jr. \& PASSARELLI, C.R 2005. El basamento cristalino de los Andes norpatagónicos en Argentina: Geocronología e interpretación tectónica. Revista Geológica de Chile, 32, 167-182.

VERVOORT, J.D. \& BLICHERT-TOFT, J. 1999. Evolution of the depleted mantle: $\mathrm{Hf}$ isotope evidence from juvenile rocks through time. Geochimica et Cosmochimica Acta, 63, 533-556.

VON GOSEN, W. 2003. Thrust tectonics in the North Patagonian Massif (Argentina): implications for a Patagonian plate. Tectonics 22, http://dx.doi. org/10.1029/2001TC901039.

WHALEN, J.B., CURRIE, K.L. \& CHAPPELL, B.W. 1987. A-type granites: Geochemical characteristics, discrimination and petrogenesis. Contributions to Mineralogy and Petrology, 95, 407-419. 